\title{
Cerebrospinal fluid markers of inflammation and infections in schizophrenia and affective disorders: a systematic review and meta-analysis
}

\author{
Sonja Orlovska-Waast ${ }^{1,2} \cdot$ Ole Köhler-Forsberg $\mathbb{1}^{1,3,4} \cdot$ Sophie Wiben Brix ${ }^{1}$ Merete Nordentoft ${ }^{1,2}$. \\ Daniel Kondziella ${ }^{5,6} \cdot$ Jesper Krogh ${ }^{1} \cdot$ Michael Eriksen Benros ${ }^{1}$
}

Received: 19 December 2017 / Revised: 1 June 2018 / Accepted: 9 July 2018 / Published online: 16 August 2018

(c) The Author(s) 2018. This article is published with open access

\begin{abstract}
Infections and inflammatory processes have been associated with the development of schizophrenia and affective disorders; however, no study has yet systematically reviewed all available studies on cerebrospinal fluid (CSF) immune alterations. We aimed to systematically review the CSF immunological findings in schizophrenia spectrum and affective disorders. We identified all studies investigating CSF inflammatory markers in persons with schizophrenia or affective disorders published prior to March 23, 2017 searching PubMed, CENTRAL, EMBASE, Psychinfo, and LILACS. Literature search, data extraction and bias assessment were performed by two independent reviewers. Meta-analyses with standardized mean difference (SMD) including 95\% confidence intervals (CI) were performed on case-healthy control studies. We identified $112 \mathrm{CSF}$ studies published between 1942-2016, and 32 case-healthy control studies could be included in meta-analyses. Studies varied regarding gender distribution, age, disease duration, treatment, investigated biomarkers, and whether recruitment happened consecutively or based on clinical indication. The CSF/serum albumin ratio was increased in schizophrenia (1 study [54 patients]; SMD =0.71; 95\% CI 0.33-1.09) and affective disorders ( 4 studies [298 patients]; $\mathrm{SMD}=0.41 ; 95 \% \mathrm{CI} 0.23-0.60, I^{2}=0 \%$ ), compared to healthy controls. Total CSF protein was elevated in both schizophrenia (3 studies [97 patients]; SMD $=0.41 ; 95 \%$ CI $0.15-0.67, I^{2}=0 \%$ ) and affective disorders ( 2 studies [53 patients]; $\mathrm{SMD}=0.80 ; 95 \% \mathrm{CI} 0.39-1.21, I^{2}=0 \%$ ). The $\mathrm{IgG}$ ratio was increased in schizophrenia ( 1 study [54 patients]; SMD $=0.68 ; 95 \%$ CI 0.30-1.06), whereas the IgG Albumin ratio was decreased (1 study [32 patients]; $\mathrm{SMD}=-0.62 ; 95 \% \mathrm{CI}-1.13$ to -0.12 ). Interleukin-6 (IL-6) levels ( 7 studies $[230$ patients]; SMD $=0.55 ; 95 \%$ CI $0.35-0.76$; $I^{2}=1 \%$ ) and IL-8 levels ( 3 studies [95 patients]; SMD $=0.46 ; 95 \%$ CI $0.17-0.75, I^{2}=0 \%$ ) were increased in schizophrenia but not significantly increased in affective disorders. Most of the remaining inflammatory markers were not significantly different compared to healthy controls in the meta-analyses. However, in the studies which did not include healthy controls, CSF abnormalities were more common, and two studies found CSF dependent re-diagnosis in 3.2-6\%. Current findings suggest that schizophrenia and affective disorders may have CSF abnormalities including signs of blood-brain barrier impairment and inflammation. However, the available evidence does not allow any firm conclusion since all studies showed at least some degree of bias and vastly lacked inclusion of confounding factors. Moreover, only few studies investigated the same parameters with healthy controls and high-quality longitudinal CSF studies are lacking, including impact of psychotropic medications, lifestyle factors and potential benefits of anti-inflammatory treatment in subgroups with CSF inflammation.
\end{abstract}

These authors contributed equally: Sonja Orlovska-Waast, Ole KöhlerForsberg, Sophie Wiben Brix.

Electronic supplementary material The online version of this article (https://doi.org/10.1038/s41380-018-0220-4) contains supplementary material, which is available to authorized users.

Michael Eriksen Benros

Benros@dadlnet.dk

Extended author information available on the last page of the article

\section{Introduction}

Immunological mechanisms in mental disorders have become an area of significant interest [1], and several studies have associated infections and autoimmune diseases with an increased risk of specifically schizophrenia and affective disorders [2-4]. Studies have also shown increased levels of peripheral pro-inflammatory markers [5-11] and genes involved in regulation of the immune system in both schizophrenia and depression [12]. Furthermore, beneficial effects 
of anti-inflammatory treatment have been found in depression [13] and subgroups with psychotic disorders [14].

However, knowledge is sparse regarding the prevalence of abnormal immunological findings in cerebrospinal fluid (CSF) of people with severe mental disorders. CSF is the biological material closest to the brain that can be easily assessed and lumbar puncture is a routine procedure in neurological but not (yet) in psychiatric practice. Nonetheless, CSF studies have revealed increased CSF/serum albumin ratio in individuals with schizophrenia and affective disorders [6, 15-25] indicating increased blood-brain barrier (BBB) permeability. Other studies found elevated CSF cell count $[15,16,20,26,27], \operatorname{IgG}$ index [16, 21], and the presence of oligoclonal bands [15, 16, 18, 20, 21] which could be indicators of inflammation and intrathecal immunoglobulin production. Also, a meta-analysis found several specific infectious agents to be associated with schizophrenia; however, most studies were based on blood and not CSF, and control groups consisted typically of non-healthy subjects [28]. Another meta-analysis found increased CSF levels of interleukin $1 \beta$ (IL-1 $\beta$ ), IL-6, and IL-8 in patients with severe mental disorders [29]. Despite these intriguing findings, no systematic review has hitherto gathered all the knowledge on infectious and inflammatory CSF abnormalities among patients with severe mental disorders.

Hence, most knowledge on the role of the immune system in mental disorders stems from studies on severe mental disorders, i.e., schizophrenia and affective disorders. Therefore, we aimed to conduct the first systematic review of all CSF studies examining inflammatory markers and infections in persons with schizophrenia spectrum or affective disorders, including meta-analyses of studies with healthy controls. Furthermore, we included the potential clinical implications of a CSF test, risk of adverse events and risk of bias.

\section{Methods}

The study protocol was a priori uploaded on PROSPERO (ID: CRD42017058938) and is available as online supplementary file.

\section{Study selection and search method}

In this systematic review we included studies investigating inflammatory markers and infections in the CSF of persons with schizophrenia spectrum disorders or affective disorders, fulfilling the following criteria:

1. Investigation of CSF markers related to inflammation or infections as defined under our primary outcomes.

2. Inclusion of persons diagnosed with schizophrenia spectrum or affective disorders according to
Diagnostic and Statistical Manual of Mental Disorders (DSM) or International Classification of Diseases (ICD) or similar classifications that might have been used before DSM and ICD implementation.

3. Publications in peer-reviewed journals.

4. Publications in English.

Studies from all time periods with study subjects in all ages, sexes, and races were included. We included both studies without controls and studies with healthy or non-healthy control groups, but only studies with healthy controls were used for the meta-analysis. The search was performed until March 23, 2017 using PubMed, CENTRAL, EMBASE, Psychinfo, and LILACS with medical subject headings (MESH) or similar when possible or text word terms: ((psychosis OR psychotic syndrome OR psychotic OR psychotic symptoms OR schizophrenia OR schizophreniform disorder OR schizoaffective OR depression OR major depressive disorder OR bipolar disorder) AND (cerebrospinal fluid OR CSF) AND (blood-brain barrier OR inflammation OR infection OR albumin OR protein OR cell count OR immunoglobulin OR IgG OR oligoclonal bands OR interleukins $O R$ cytokine $O R$ autoimmune disease $O R$ autoimmunity OR immunology OR immune system OR psychoneuroimmunology OR lymphocyte $O R$ macrophage OR $C$-reactive protein OR autoantibodies $O R T$ cells $O R$ complement)). Reference lists of relevant reviews were searched for additional studies. Two investigators (SO and SWB) examined titles and abstracts to remove irrelevant reports and examined full texts to determine compliance with inclusion criteria.

\section{Outcomes}

\section{Primary outcomes}

1. Basic CSF findings: cell count, total protein, albumin, and albumin ratio.

2. CSF inflammatory markers: immunoglobulins, oligoclonal bands, and cytokines.

3. Specific CSF antibodies: antibodies directed against infectious agents as an indicator of preceding or current infection and auto-antibodies.

\section{Secondary outcomes}

1. Correlation between CSF findings and serum findings, psychotropic medication, and psychiatric symptoms, respectively.

2. Change in diagnosis following CSF analyses.

3. Adverse events in relation to lumbar puncture, e.g., headache. 


\section{Data extraction and bias assessment}

Two authors (SO and OKF) extracted data using a pre-piloted structured form not blinded to study results, author names or institutions. This included bibliographical data and participant description. Authors were contacted by e-mail in case of missing details with a reminder sent in case of no response. Two authors (SO and OKF) conducted bias assessment according to the Newcastle-Ottawa criteria for case-control studies as suggested by the Cochrane collaboration (eMethods).

\section{Statistical analysis}

The primary analyses were conducted using RevMan 5.0. When fixed-effects analysis and the random-effects analysis resulted in similar results, only findings from the random effects analysis were reported, but in case of discrepancies both results were reported. We conducted analysis using the standardized mean difference (SMD) since we expected differences in assays. SMD is the mean difference in outcome between cases and controls divided by the pooled standard deviation (SD) giving the result of a unit free effect size. By convention, SMD effect sizes of $0.2,0.5$, and 0.8 are considered small, medium and large effect sizes. Our conclusions were based on the SMD even though we also present results from mean difference. The chi-squared test for heterogeneity will be used to provide an indication of between-trial heterogeneity. In addition, the degree of heterogeneity observed in the results was quantified using the $I^{2}$ statistic, which can be interpreted as the percentage of variation observed between the trials attributable to between trial differences rather than sampling error (chance).

\section{Post-hoc analyses}

First, since CSF analysis techniques have improved over time, we performed sensitivity analyses on studies published after the year 2000. Second, we divided patients with psychosis into acute (inpatient treatment) and chronic (recruited in an outpatient setting) psychosis and performed analyses if there were at least two studies in each group, i.e., acute versus chronic.

\section{Results}

\section{Search results and study characteristics}

We identified 6571 studies (Fig. 1), of which 229 were assessed for full-text inspection. A total of 112 studies investigated CSF immune-related alterations, out of which
38 studies included control groups consisting solely of healthy controls. Data from 32 studies had data necessary for conducting meta-analyses, either published or send to us by the authors. Study characteristics are described in Table 1. Briefly, studies varied regarding gender distribution, age, disease duration, treatment, investigated biomarkers, and whether recruitment happened consecutively or based on clinical indication. In the following sections, the meta-analysis results are presented first (the findings on each specific CSF marker are shown in Table 2 and eTable 1 with forest plots in Figure 2 and eFigure 1) followed by a summary of the remaining CSF studies without healthy controls. Additional analyses only including studies published after the year 2000 supported the primary analyses (eFigure 2). The study characteristics, baseline data, and results for studies without controls or with non-healthy controls are shown in eTables 2 and 3, while results from the studies combining cases with schizophrenia spectrum and affective disorders are presented in the Results.

\section{Bias assessment}

All studies included in the meta-analysis showed at least some degree of bias (eTable 4). The majority of studies were biased concerning the actual case definition (16/32), representativeness of cases (28/32), random selection of controls (20/32), comparability between cases and controls (21/32) and ascertainment of exposure (27/32).

\section{Primary outcomes}

\section{CSF cell count, total protein, albumin, and albumin ratio}

\section{Schizophrenia spectrum disorders}

In the meta-analysis comparing to healthy controls, total protein (3 studies [97 patients]; SMD: 0.41; 95\% CI $\left.0.15-0.67 ; I^{2}=0 \%\right)$ and albumin ratios (1 study [54 patients]; SMD: $0.71 ; 95 \%$ CI $0.33-1.09)$ were elevated, whereas albumin and cell counts were not significantly increased.

Across all CSF studies, cell counts ranged from normal $[18,19,23,30-36]$ to increased levels in up to $3.4 \%$ of the cases $[20,26]$ with no difference comparing to neurological controls [37]. Total protein levels varied from normal [18, 22, $30,31]$ to increased in up to $42.2 \%$ of cases $[6,20,26,38$, 39 ], with no difference in the studies comparing to neurological, psychiatric, surgical or healthy controls [32, 40-43]. Albumin levels ranged from normal $[18,22,30,31]$ to increased in up to $16 \%$ of cases $[6,24,39]$, with no difference in the studies comparing with psychiatric controls [40] or a combined group of healthy and psychiatric controls [38]. The 
Fig. 1 Flowchart of literature search and study selection

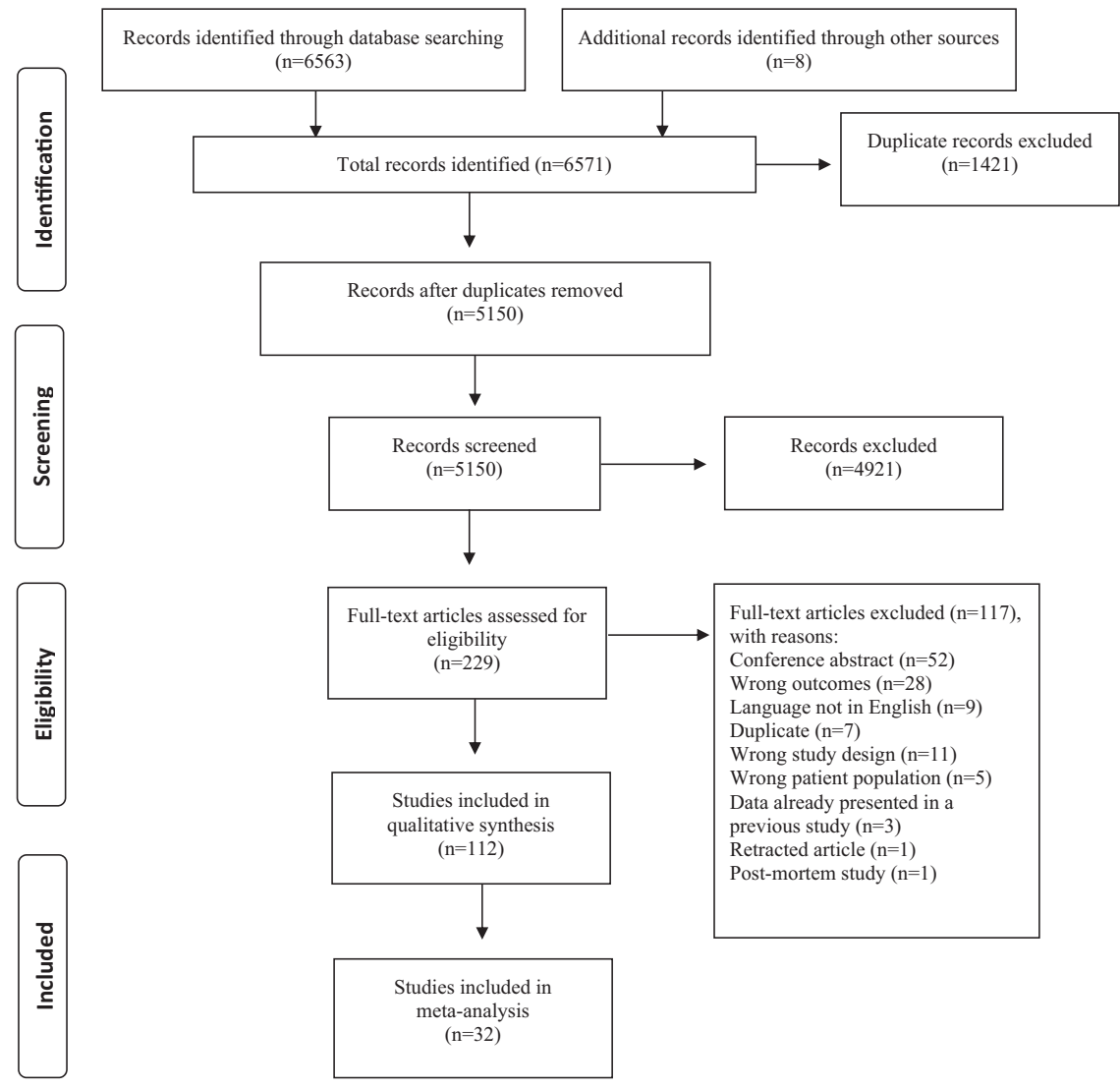

albumin ratio ranged from normal [36, 37, 44, 45] to increased in up to $53 \%$ of the cases [6, 19-25], with no difference in the studies comparing to healthy controls [25] or a combined group of healthy and psychiatric controls [38].

\section{Affective disorders}

In the meta-analysis comparing to healthy controls, cell count was not significantly increased, whereas total protein levels (2 studies [53 patients]; SMD: 0.80; 95\% CI $0.39-1.21, I^{2}=0 \%$ ), albumin (4 studies [181 patients]; $\left.\mathrm{SMD}=0.28 ; 95 \% \mathrm{CI} 0.04-0.52, I^{2}=0\right)$ and albumin ratio were increased (4 studies [298 patients]; $\mathrm{SMD}=0.41$; 95\% CI $\left.0.23-0.60, I^{2}=0\right)$.

Across all CSF studies, cases had normal [18, 46] or increased cell counts in up to $13.1 \%$ [15, 16, 27], with no difference in the studies comparing to neurological controls $[15,47]$. Total protein ranged from normal [18, 47, 48] to increased levels in up to $36.6 \%$ of cases [16, 27, 49], with no difference in the studies comparing to psychiatric or neurological controls [16, 40, 47]. Albumin was not different compared to somatically ill or psychiatric controls $[40,50]$. The albumin ratio was increased in up to $44 \%$ of cases [15-18] but with no difference in the studies comparing with neurological controls $[15,16]$.

\section{CSF immunoglobulins}

\section{Schizophrenia spectrum disorders}

In the meta-analysis comparing to healthy controls, IgG/albumin ratio was decreased (1 study [32 patients]; $\mathrm{SMD}=-0.62 ; 95 \% \mathrm{CI}-1.13$ to -0.12$), \mathrm{IgG}$ ratio was increased (1 study [54 patients]; SMD $=0.68 ; 95 \%$ CI 0.30-1.06), whereas IgG levels and the IgG index were not significantly increased.

In the other CSF studies, immunoglobulins were increased in $3 \%$ of the cases [51], whereas $\operatorname{IgG}$ and the $\mathrm{IgG}$ index were normal $[19,22,36,50]$ or increased in up to $33 \%[6,19,21,24,52]$ of cases, respectively. In the studies comparing with surgical, neurological or a combined group of psychiatric and healthy controls, the $\operatorname{IgG}$ ratio, $\operatorname{IgG}, \operatorname{Ig}$ A and $\operatorname{IgM}$ were decreased [32, 53] or not different in cases $[22,38,50]$. Oligoclonal bands were absent in some reports $[18,36,54]$ but present in up to $12.5 \%$ of cases in others [20, 21]. An intrathecal immunoglobulin synthesis was observed in none [18] to $7.2 \%$ of cases [20]. 


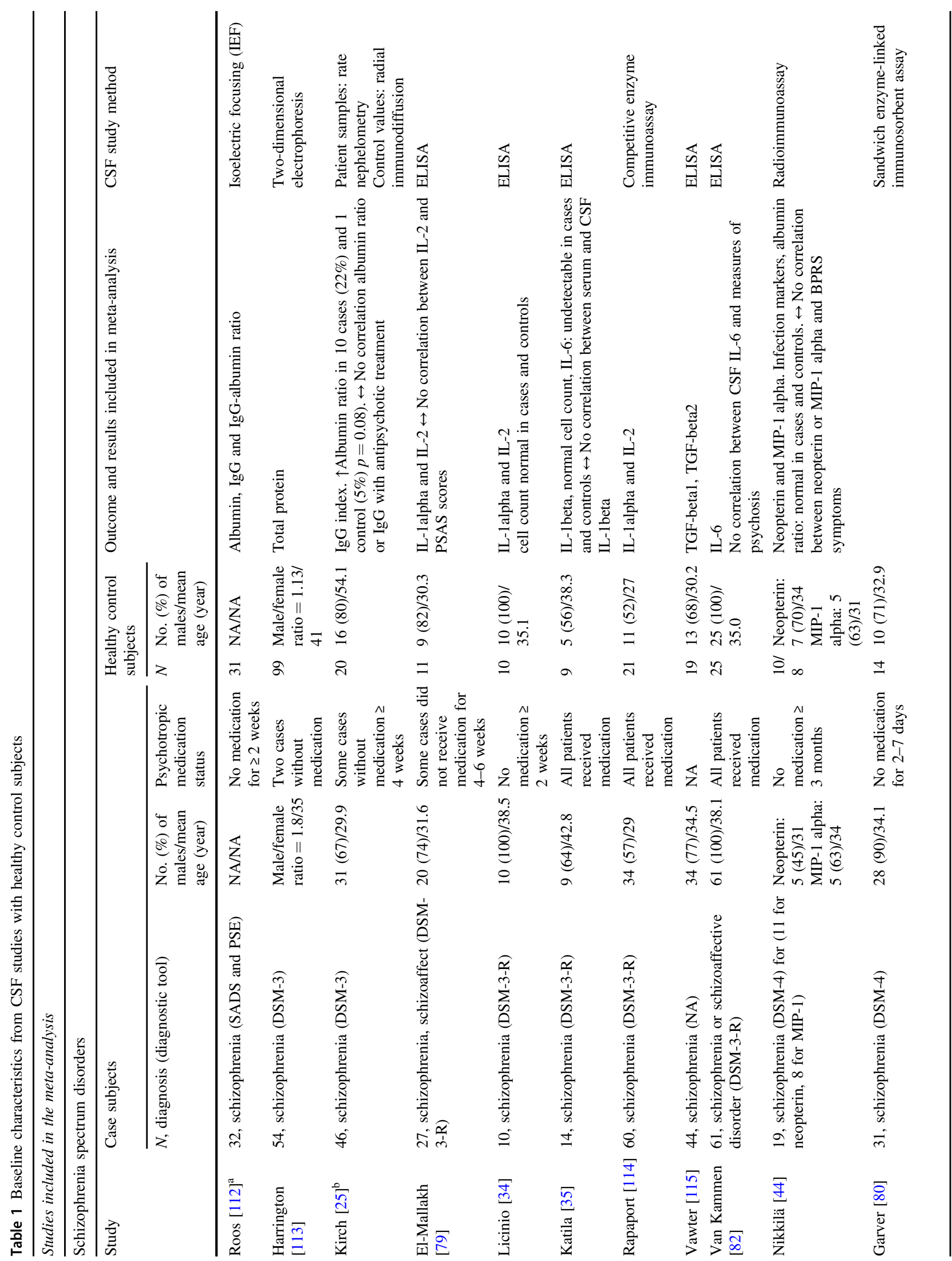




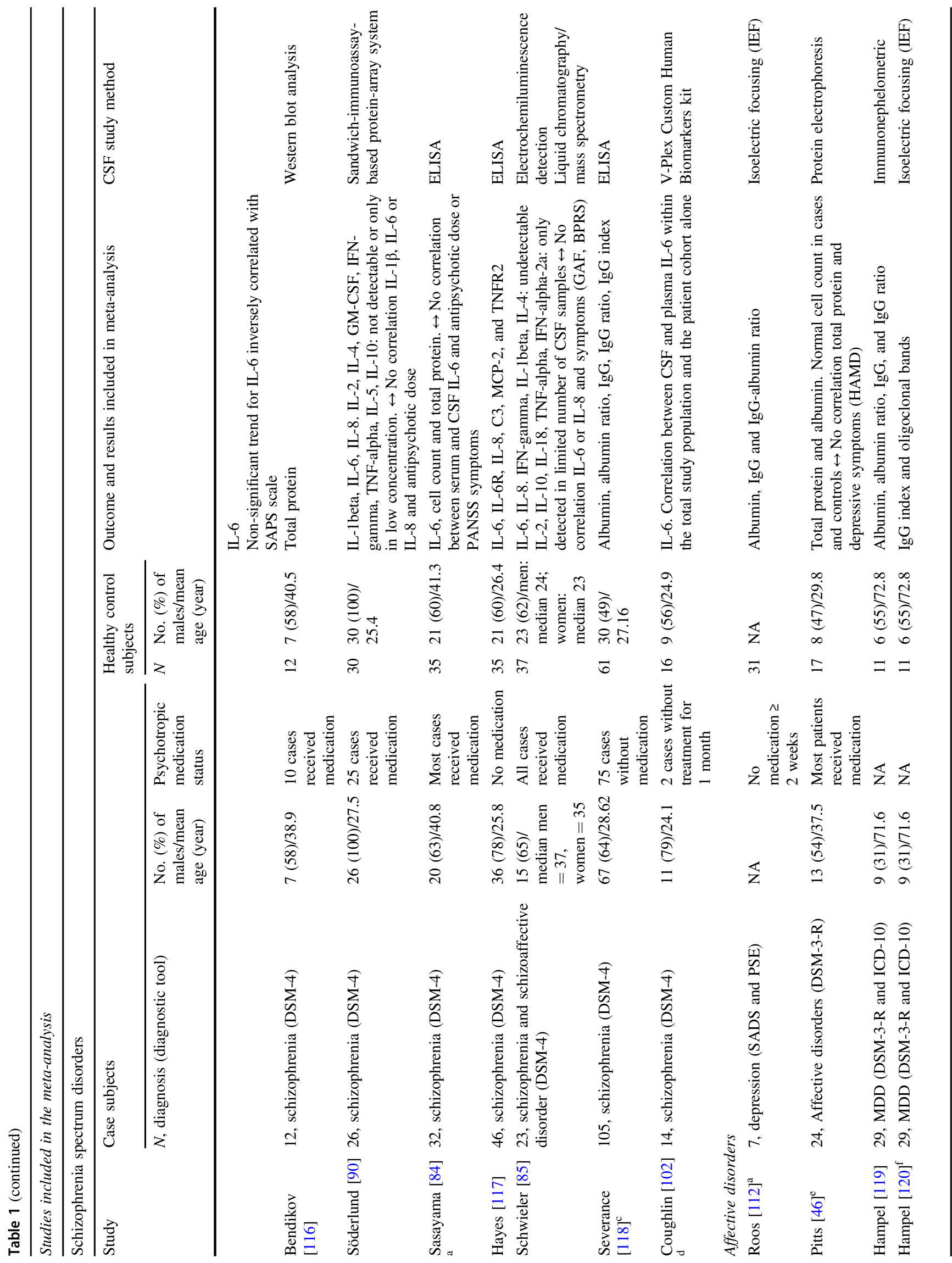




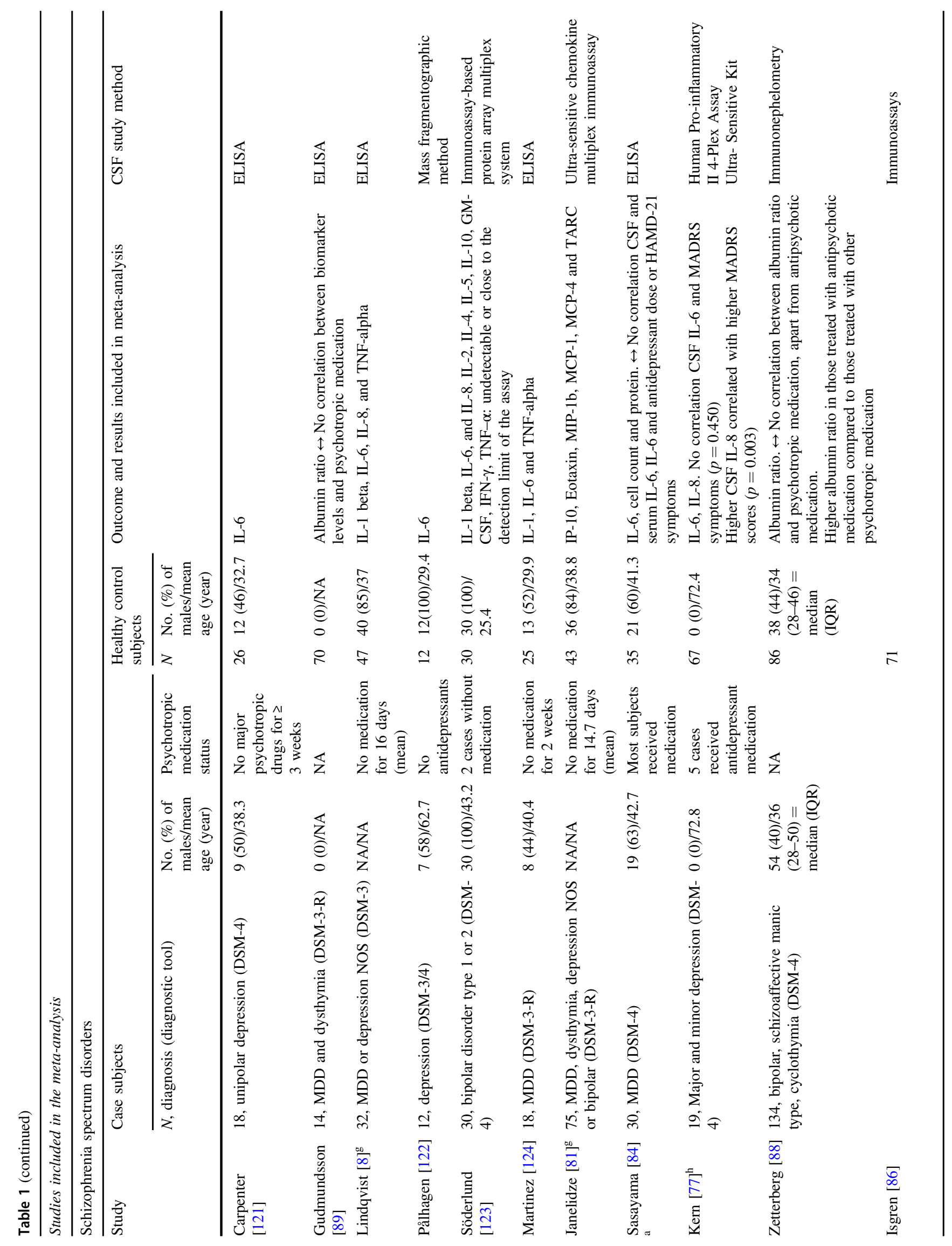




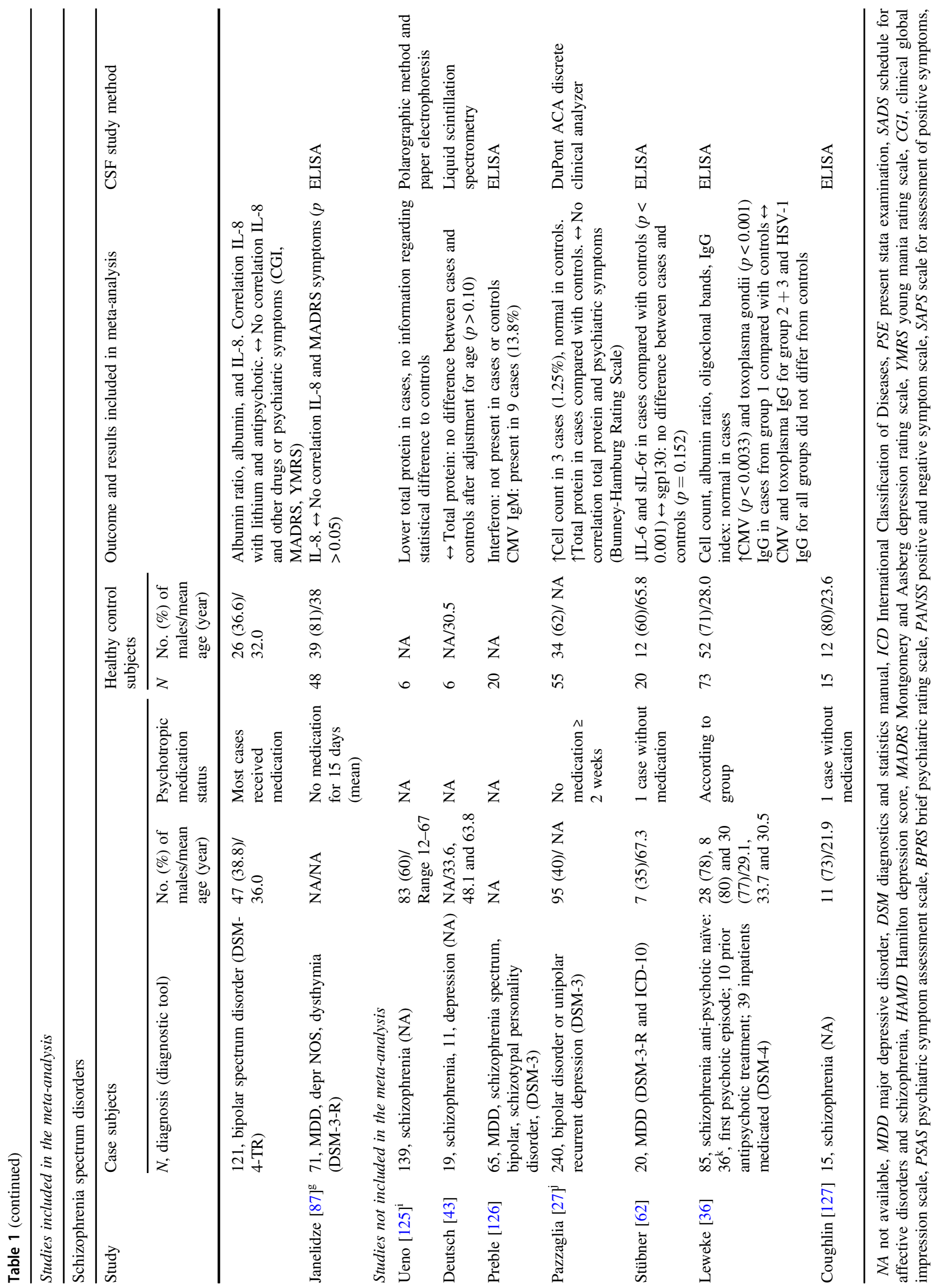




\section{Affective disorders}

In the meta-analysis, $\mathrm{IgG}$ levels, the $\mathrm{IgG} /$ albumin ratio, the $\mathrm{IgG}$ ratio and the $\mathrm{IgG}$ index were not significantly different compared to healthy controls.

In studies not included in the meta-analysis $\mathrm{IgG}$ was present in all cases [55], with increased levels of IgG [49] but within normal range $\mathrm{IgG}$ ratio [16]; however, the $\mathrm{IgG}$ index was significantly higher in cases in the one study comparing with neurological controls [16]. IgM was not present in cases $[49,55]$ while $\operatorname{IgA}$ was present in $23.3 \%$ $[49,55]$. Oligoclonal bands were found in up to $12.5 \%$ of cases $[15,16,18]$ with no difference in the studies comparing to neurological controls $[15,16]$. Intrathecal immune response was present in none [18] to $30 \%$ of cases and significantly increased in the study comparing with neurological controls [16].

\section{CSF interleukins}

\section{Schizophrenia spectrum disorders}

In the meta-analysis comparing to healthy controls, IL-8 (3 studies [95 patients]; SMD =0.46; 95\% CI 0.17-0.75; $\left.I^{2}=0 \%\right)$ and IL-6 (7 studies [230 patients]; $\mathrm{SMD}=0.55$; $95 \%$ CI $0.35-0.76 ; I^{2}=1 \%$ ) were significantly increased. In a post-hoc analysis, we found that IL-6 was significantly elevated in acute psychosis $(\mathrm{SMD}=0.46 ; 95 \%$ CI $0.22-0.71 ; I^{2}=1 \%$ ) and chronic psychosis $(\mathrm{SMD}=$ $0.75 ; 95 \%$ CI 0.39 to $1.12 ; I^{2}=0 \%$ ) with the betweengroup difference being not significant $(p=0.20)$ (eFigure 3 ). The levels of IL-1alpha, IL-1beta and IL-2 were not statistically different from healthy controls.

In the studies not included in the meta-analysis, the anti-inflammatory cytokines IL-4 and IL-10 were present in 64 and $14 \%$ of cases, respectively. Concerning proinflammatory cytokines, IL-2 was detected in 95\%, IL-5 in $40 \%$, IFN-gamma in 14\%, TNF-beta in $41 \%$, and TNFalpha in $50 \%$ of cases [7]. Other studies found no difference to neurological controls in levels of IL-2, IL-6, and TNF alpha [33] or decreased levels of IL-1beta, sIL2r [33], and TNF-alpha [56] compared to neurological and surgical controls. Interferon was reported to be absent [31] or present in up to 59\% of cases [57-60] but with no difference in the study comparing to psychiatric controls [60].

\section{Affective disorders}

In the meta-analysis comparing to healthy controls, IL-1, IL-1beta, IL-6, IL-8, and TNF-alpha were not significantly increased (Table 2, Fig. 2 and eFigure 1). 
Table 2 CSF immune related markers in patients with schizophrenia spectrum or affective disorders compared to healthy controls

\begin{tabular}{|c|c|c|c|c|c|c|c|}
\hline CSF Marker & Studies & Cases & Control & SMD & $95 \% \mathrm{CI}$ & $p$-value & $I^{2}$ \\
\hline \multicolumn{8}{|c|}{ Schizophrenia vs healthy controls } \\
\hline Cell count & 1 & 32 & 31 & 0.19 & -0.31 to 0.68 & 0.46 & NA \\
\hline Total protein & 3 & 97 & 142 & 0.41 & 0.15 to 0.67 & 0.002 & $0 \%$ \\
\hline Albumin & 2 & 86 & 91 & 0.21 & -0.29 to 0.70 & 0.41 & $62 \%$ \\
\hline Albumin ratio & 1 & 54 & 60 & 0.71 & 0.33 to 1.09 & 0.0002 & NA \\
\hline $\mathrm{IgG}$ & 2 & 86 & 91 & -0.12 & -0.93 to 0.69 & 0.77 & $85 \%$ \\
\hline IgG Ratio & 1 & 54 & 60 & 0.68 & 0.30 to 1.06 & 0.0004 & NA \\
\hline IgG/Albumin ratio & 1 & 32 & 31 & -0.62 & -1.13 to -0.12 & 0.02 & NA \\
\hline IgG Index & 2 & 100 & 80 & 0.25 & -0.07 to 0.56 & 0.13 & $7 \%$ \\
\hline IL-1 alpha & 3 & 72 & 33 & -0.16 & -0.91 to 0.60 & 0.68 & $43 \%$ \\
\hline IL-1 Beta & 2 & 40 & 39 & -0.13 & -4.96 to 4.71 & 0.96 & $98 \%$ \\
\hline IL-2 & 3 & 97 & 42 & 0.18 & -0.49 to 0.85 & 0.60 & $64 \%$ \\
\hline IL-6 & 7 & 230 & 188 & 0.55 & 0.35 to 0.76 & $<0.00001$ & $1 \%$ \\
\hline IL-6R & 1 & 46 & 35 & -0.24 & -0.68 to 0.20 & 0.28 & NA \\
\hline IL-8 & 3 & 95 & 102 & 0.46 & 0.17 to 0.75 & 0.002 & $0 \%$ \\
\hline Neopterin & 1 & 11 & 10 & -0.05 & -0.91 to 0.81 & 0.91 & NA \\
\hline MIP-1 alfa & 1 & 8 & 8 & -0.70 & -1.72 to 0.32 & 0.18 & NA \\
\hline $\mathrm{C} 3$ & 1 & 46 & 35 & 0.00 & -0.44 to 0.44 & 1.00 & NA \\
\hline МCP-2 & 1 & 46 & 35 & 0.26 & -0.18 to 0.71 & 0.24 & NA \\
\hline TNFR2 & 1 & 46 & 35 & 0.06 & -0.38 to 0.50 & 0.78 & NA \\
\hline TGFB1 & 1 & 44 & 19 & 0.29 & -0.25 to 0.83 & 0.29 & NA \\
\hline TGFB2 & 1 & 44 & 19 & -0.14 & -0.68 to 0.40 & 0.61 & NA \\
\hline \multicolumn{8}{|c|}{ Affective Disorders vs healthy controls } \\
\hline CSF Marker & Studies & Cases & Control & Mean ES & $95 \% \mathrm{CI}$ & $p$-value & $I^{2}$ \\
\hline Cell count & 1 & 29 & 31 & 0.40 & -0.11 to 0.91 & 0.13 & NA \\
\hline Total protein & 2 & 53 & 48 & 0.80 & 0.39 to 1.21 & 0.0001 & $0 \%$ \\
\hline Albumin & 4 & 181 & 130 & 0.28 & 0.04 to 0.52 & 0.02 & $0 \%$ \\
\hline Albumin ratio & 4 & 298 & 238 & 0.41 & 0.23 to 0.60 & $<0.00001$ & $0 \%$ \\
\hline $\operatorname{IgG}$ & 2 & 36 & 42 & -0.22 & -0.75 to 0.32 & 0.43 & $0 \%$ \\
\hline IgG Ratio & 1 & 29 & 11 & 0.33 & -0.37 to 1.02 & 0.36 & NA \\
\hline IgG/Albumin ratio & 1 & 7 & 31 & -0.56 & -1.39 to 0.28 & 0.19 & NA \\
\hline IgG Index & 1 & 29 & 11 & 0.22 & -0.48 to 0.91 & 0.54 & NA \\
\hline IL-1 & 1 & 18 & 25 & 0.61 & -0.01 to 1.23 & 0.05 & NA \\
\hline IL-1 Beta & 2 & 62 & 77 & 0.80 & -0.99 to 2.59 & 0.38 & $96 \%$ \\
\hline IL-6 & 7 & 159 & 242 & 0.22 & -0.23 to 0.68 & 0.34 & $78 \%$ \\
\hline IL-8 & 5 & 273 & 263 & 0.17 & -0.21 to 0.56 & 0.37 & $76 \%$ \\
\hline TNF-alpha & 2 & 50 & 72 & 0.24 & -0.12 to 0.61 & 0.19 & $0 \%$ \\
\hline Eotaxin-1 & 1 & 75 & 43 & -0.33 & -0.71 to 0.04 & 0.08 & NA \\
\hline IP-10 & 1 & 75 & 43 & -0.17 & -0.55 to 0.20 & 0.37 & NA \\
\hline MIP-1B & 1 & 75 & 43 & -0.26 & -0.64 to 0.12 & 0.17 & NA \\
\hline MCP-1 & 1 & 75 & 43 & -0.28 & -0.65 to 0.10 & 0.15 & NA \\
\hline MCP-4 & 1 & 75 & 43 & -0.76 & -1.15 to -0.37 & 0.0001 & NA \\
\hline TARC & 1 & 75 & 43 & -0.57 & -0.95 to -0.19 & 0.004 & NA \\
\hline
\end{tabular}

The studies comparing neurological $[47,61]$ and healthy [62] controls that were not included in the meta-analysis, showed that cases had decreased or unchanged levels of IL6 [61-63], decreased levels of sIL-6r [62] and sIL-2r [47], increased levels of IL-1beta [61, 63], and unchanged levels of TNF-alpha [61] and sgp130 [62]. Moreover, a wide range of inflammatory markers were found to be similar in psychiatric patients compared to neurological controls (eTable 1) [63]. IL-7, IL-12, or granulocyte-colony stimulating factor (G-CSF) were not detected [63]. 


\section{Specific CSF antibodies}

\section{Schizophrenia spectrum disorders}

One study with healthy controls found increased CMV and toxoplasma gondii IgG in antipsychotic naïve cases [36], but the data were not suitable for meta-analysis. Other studies found that CMV antibodies [48, 64-68] were either undetectable $[48,64-68]$ or present (in up to $18.5 \%$ of cases; $43,66,67$ ), but this was not different from surgical [32] or psychiatric and healthy controls $[38,69]$. HSV-1 or 2 antibodies were undetectable in one [19] but detectable in the other studies (present in up to $69 \%$ of cases) $[48,57-59,64,67,70]$, but without difference in the studies comparing to neurological, surgical controls, psychiatric or healthy controls $[30,32,36,38]$.

Studies found antibodies in cases against mumps in $2.9 \%$ [64] (but decreased compared with surgical controls [32]), VZV in 5.7\% [64], tick-borne encephalitis virus in $7.3 \%$, orbivirus lipovnik in up to $2.9 \%$, choriomeningitis virus in $5.3 \%$ [57], and nucleotide sequences homologous to those of known retroviruses in $20 \%$ of cases [71], whereas others did not find CSF antibodies against infectious agents $[19,30,39,64,66,72,73]$. There was no difference in the

\section{Schizophrenia spectrum disorders vs. healthy controls:}

1) Total protein, $\mathrm{mg} / \mathrm{dL}$

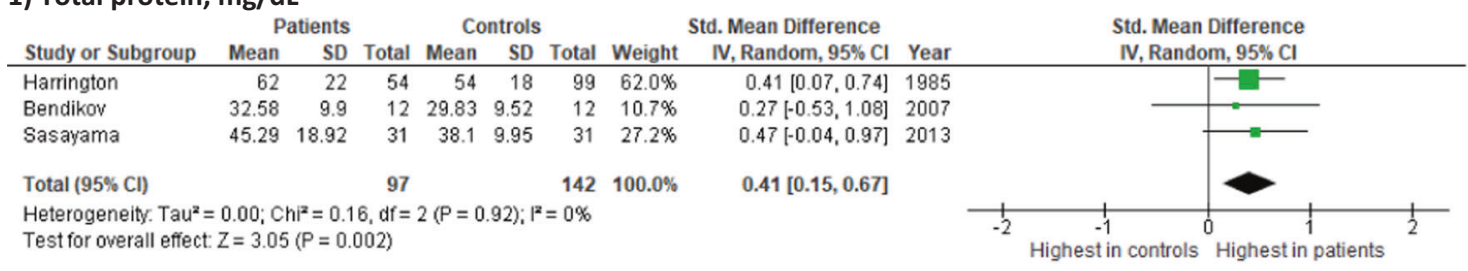

2) Albumin, $\mathrm{mg} / \mathrm{dL}$

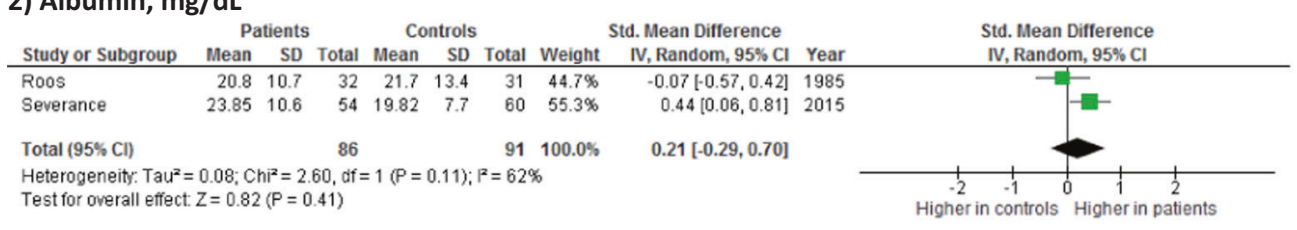

3) Albumin ratio

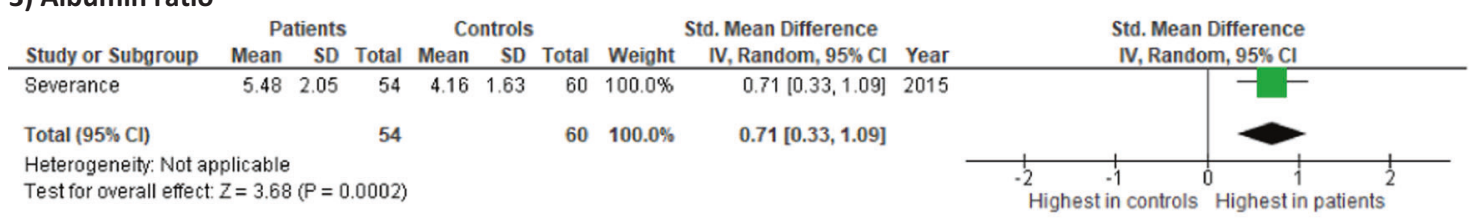

4) IL-6, ng/mL

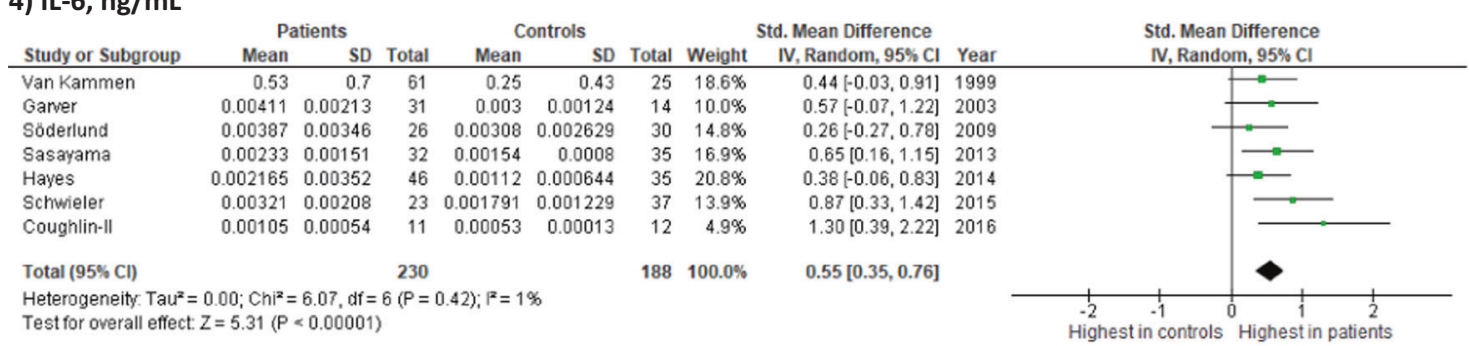

5) IL-8, pg/mL

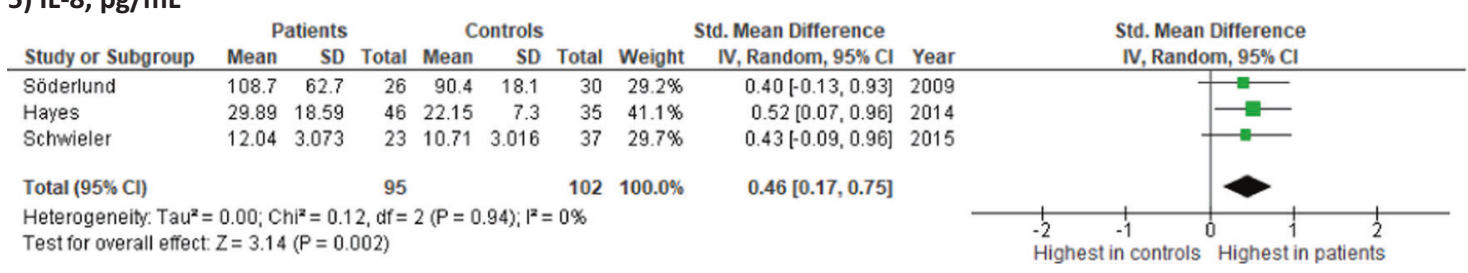


Affective disorders vs. healthy controls:

1) Total protein, $\mathrm{mg} / \mathrm{dL}$

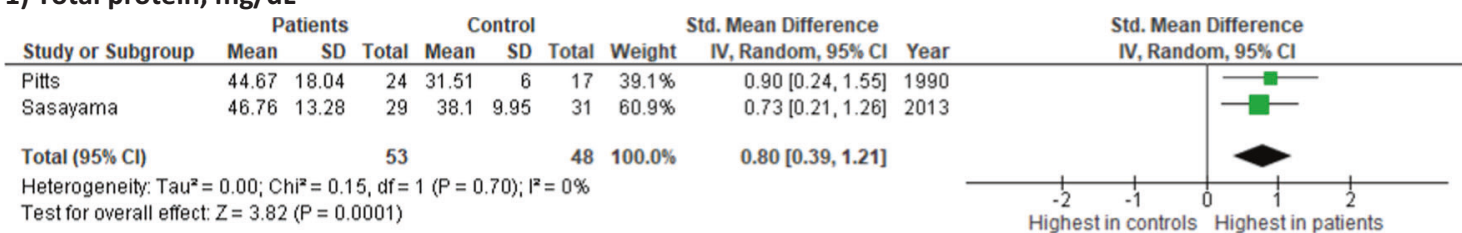

2) Albumin, $\mathrm{mg} / \mathrm{dL}$

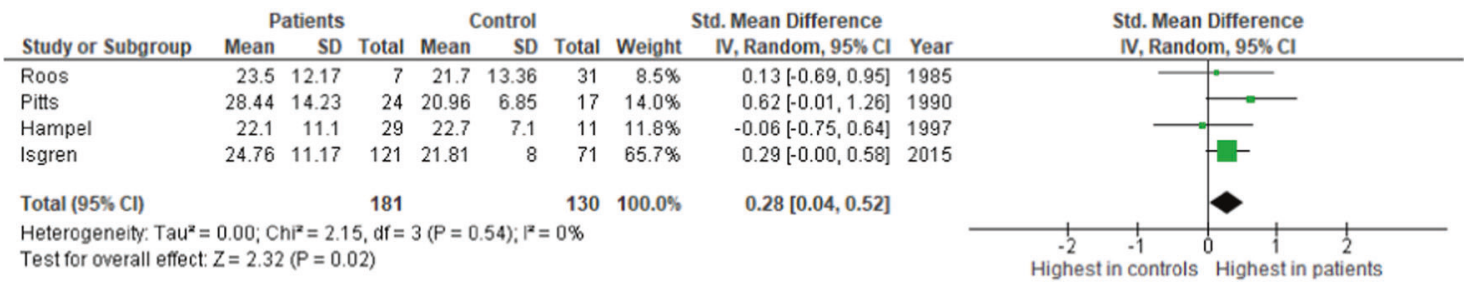

3) Albumin ratio

\begin{tabular}{|c|c|c|c|c|c|c|c|c|c|c|c|}
\hline Study or Subgroup & \multicolumn{3}{|c|}{ Patients } & \multicolumn{3}{|c|}{ Control } & \multicolumn{3}{|c|}{ Std. Mean Difference } & \multicolumn{2}{|c|}{$\begin{array}{l}\text { Std. Mean Difference } \\
\text { IV, Random, } 95 \% \mathrm{Cl}\end{array}$} \\
\hline Gudmundsson & 6.7 & 2.6 & 14 & 5.4 & 1.7 & 70 & $9.9 \%$ & $0.69[0.10,1.27]$ & 2007 & & \\
\hline Isgren & 5.9 & 2.64 & 121 & 4.98 & 1.83 & 71 & $38.4 \%$ & $0.39[0.09,0.68]$ & 2015 & & $\rightarrow$ \\
\hline \multirow{2}{*}{\multicolumn{7}{|c|}{ 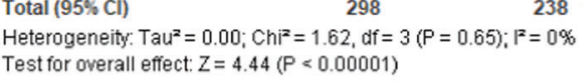 }} & $100.0 \%$ & $0.41[0.23,0.60]$ & & & \\
\hline & & & & & & & & & & $\begin{array}{cc}-2 & -1 \\
\text { Highest in controls }\end{array}$ & $\begin{array}{ccc}0 & 1 & 2 \\
\text { Highest in patients }\end{array}$ \\
\hline
\end{tabular}

\section{4) IL-6, pg/mL}

\begin{tabular}{|c|c|c|c|c|c|c|c|c|c|c|}
\hline Study or Subgroup & \multicolumn{3}{|c|}{ Patients } & \multicolumn{3}{|c|}{ Control } & \multicolumn{3}{|c|}{ Std. Mean Difference } & $\begin{array}{l}\text { Std. Mean Difference } \\
\text { IV, Random, } 95 \% \mathrm{CI}\end{array}$ \\
\hline Lindqvist & 3.02 & 9.21 & 32 & 0.64 & 0.62 & 47 & $15.7 \%$ & $0.40[-0.05,0.86]$ & 2009 & \\
\hline Martinez & 0.066 & 0.01 & 18 & 0.06 & 0.007 & 25 & $13.7 \%$ & $0.70[0.08,1.33]$ & 2012 & \\
\hline Sasayama & 2.14 & 1.22 & 30 & 1.54 & 0.8 & 35 & $15.2 \%$ & $0.58[0.09,1.08]$ & 2013 & \\
\hline Kern & 3.4 & 4.3 & 19 & 1.9 & 1.8 & 67 & $15.0 \%$ & $0.58[0.07,1.10]$ & 2014 & \\
\hline \multicolumn{10}{|c|}{$\begin{array}{l}\text { Heterogeneity: } \operatorname{Tau}^{2}=0.29 ; \mathrm{Chi}^{2}=27.64, \mathrm{df}=6(P=0.0001) ; \mathrm{I}^{2}=78 \% \\
\text { Test for overall effect: } Z=0.95(P=0.34)\end{array}$} & 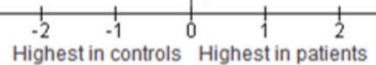 \\
\hline
\end{tabular}

\section{5) IL-8, $\mathrm{pg} / \mathrm{mL}$}

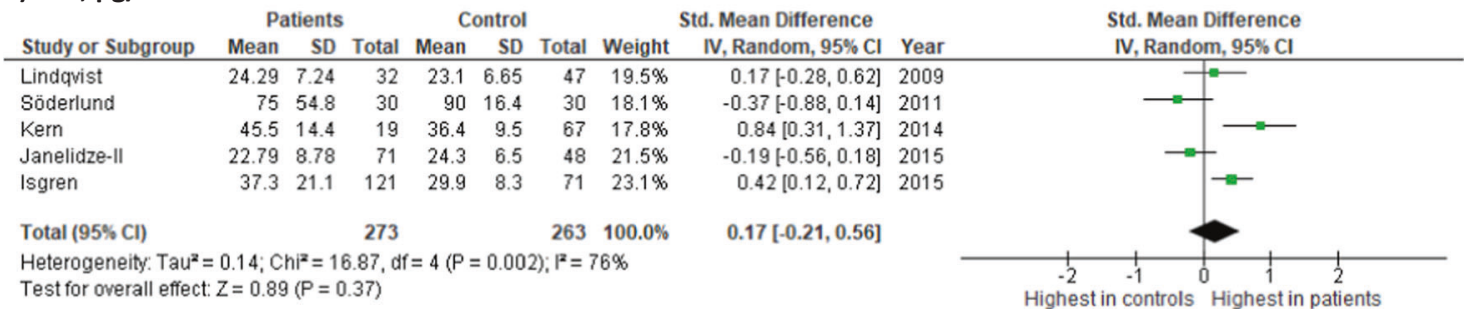

Fig. 2 Forest plots on selected results from studies investigating immune-related CSF markers in schizophrenia spectrum and affective disorders (the remaining forest plots are shown in eFigure 1)

levels of antibodies towards measles [32], rubella [30, 32], VZV [32], adenovirus [32], vaccinia [38], or influenza [38] between cases and surgical $[30,32]$, psychiatric or healthy controls [38].

Antibodies against neuronal cell surface antigens were detected in up to $2.4 \%$ and against intracellular onconeural antigens in up to $2.1 \%$ of cases but none against intracellular synaptic antigens in cases [20]. Others found anti-brain antibodies in $48.1 \%$ of cases [74], with a study finding dopamine $\mathrm{IgG}$ in $100 \%$ of cases and significantly elevated compared to the $41 \%$ of neurological controls [22]. No difference of antibodies against myelin basic protein and glial fibrillary acidic protein was observed compared to surgical controls [31]. 


\section{Affective disorders}

Studies found CSF antibodies against toxoplasma gondii in $52.5 \%$ [16], HSV in up to $85 \%$, EBV in up to $60 \%[16,48]$, CMV in $3 \%$ [72] and BDV in up to $50 \%[16,45]$ of cases. Others found no antibodies against measles [48], CMV [48], or treponema pallidum [73] in cases. There were no antibodies against intracellular antigens or neuronal cell surface antigens $[75,76]$.

\section{Secondary outcomes}

\section{Correlation between CSF findings and psychiatric symptoms}

Correlations have been found between albumin and IgG with SANS scores [6], and higher IL-8 levels with higher MADRS scores [77]. However, most authors reported no correlation between psychiatric symptoms and the following CSF findings: total protein [27, 46], impairment of the BBB [51], IL-1alpha [78], IL-1beta [61], IL-2 [78, 79], IL-6 [80-85], sIL-6r [24], IL-8 [85-87], IL-10 [83], IL-15 [63], TNF-alpha [56], neopterin [44], MIP-1alpha [44], MCP-1 [63], and lymphocyte activational stage [40].

\section{Correlation between CSF findings and psychotropic medication}

A total of 17 studies investigated the association between medication and CSF findings. CSF analysis in patients on antipsychotic medication revealed a tendency towards normalization of the CSF cytological alterations [37]. There was a correlation between higher albumin ratio and IL-1alpha with antipsychotic treatment [78, 88], IL-8 and the use of lithium or antipsychotics but not the use of other psychotropic medication [86]. However, most studies found no correlation between antipsychotic or antidepressant medication and CSF levels of $\operatorname{IgG}, \operatorname{IgM}$, IgA [53], IgG index [25], total protein [73], albumin ratio [88, 89], CMV IgM [45], lymphocytic profile [23], IL-1 beta, IL-2, sIL-2r, IL-6, IL-8, and TNF alpha $[33,78,84,85,90]$, or impairment of the BBB $[19,21$, $25,51,91]$.

\section{Change of diagnosis after CSF analyses}

Two studies reported that 3.2\% $(N=5 / 155)$ [92], respectively, $6 \%(N=4 / 63)$ [93] of patients with initial diagnoses of affective [93] or schizophrenia spectrum disorders [92, 93] received a revised diagnosis following CSF analyses, including infections and autoimmune disorders.
Adverse events after lumbar puncture

Only one study reported on adverse events related to the lumbar puncture and found that mild to moderate adverse events (mostly headaches or local pain at the puncture site) occurred in $10.3 \%$ of the cases; $1.3 \%$ experienced severe post-lumbar puncture headache with nausea [92].

\section{Discussion}

This is the first systematic review and meta-analysis of the available evidence from eight decades on immune-related CSF investigations in schizophrenia and affective disorders, including previously unpublished data acquired from contacts to the study authors. Our meta-analysis pointed towards BBB impairment with increased albumin ratio and total protein in schizophrenia and affective disorders, and increased levels of albumin in affective disorders. The increased $\operatorname{IgG} \mathrm{CSF} /$ serum ratio (and a non-significantly increased IgG index) in schizophrenia might suggest intrathecal IgG production. Moreover, IL-6 and IL-8 levels were increased in schizophrenia but not significantly increased in affective disorders. However, all studies included in the meta-analysis showed at least some degree of bias, specifically concerning representativeness of cases and ascertainment of exposure.

The major limitation was the small number of studies with healthy controls; hence, the largest meta-analysis included 4 studies with 302 cases. Several meta-analyses were based on one study. The remaining part of the systematic review consisted of studies with non-healthy control groups or without a control group lowering the reliability. Second, detailed study protocols were commonly unavailable, case groups were often unsystematically identified and consisted of various diagnostic categories with variable disease duration, severity and age of onset, making it difficult to apply the results to specific patient groups. Third, CSF analysis varied according to sampling time points and sensitivity of the cytokine assays, and many studies did not disclose the number of samples above the detection limit. In addition, assays have developed over time and hence studies used different techniques, and particularly the broad spectrum of new and more sensitive methods has been emphasized by several studies [94, 95]. Fourth, the majority of studies were cross-sectional. Fifth, we could not perform meta-analyses on studies investigating the importance of psychotropic medication nor could we identify longitudinal studies investigating psychotropic medication. Furthermore, studies with healthy controls examining a broad range of immune-related CSF markers were lacking. Sixth, we only included articles written in English and geographic biases 
might occur as clinicians may be more likely to perform lumbar punctures in areas where infections with treatable infectious agents are prevalent. Seventh, several studies did not match on important factors such as age or gender (eTable 4) and did not control for important confounders such as BMI, smoking or diet. These confounding factors have been shown to largely influence the associations between at least peripheral inflammatory markers and depression [96], which need to be considered in future studies also for CSF inflammatory markers. Finally, we had no knowledge regarding longitudinal data relating to clinical state and severity of the disorder or response to medications.

The major findings in our meta-analysis were increased albumin ratios and total protein suggestive of BBB leakage or dysfunction. Supporting this, studies have found an increased albumin ratio in up to 53\% with schizophrenia spectrum disorders $[6,19-25]$ and $44 \%$ with affective disorders [15-18]. An impaired BBB may leave the brain more vulnerable to harmful substances in the blood, including immune components. It might also be an indicator of inflammation within the central nervous system (CNS), which is also indicated by the non-significantly increased CSF cell counts.

Our meta-analysis reveals evidence for intrathecal $\mathrm{IgG}$ production in a subset of psychiatric patients [20,93] and oligoclonal bands were increased in up to $12.5 \%$ of cases $[15,16,18,20,21]$, which may indicate acute or chronic inflammation, an "immunological scar" from previous inflammation of brain tissue, immunoglobulin production or a local B cell immune response in certain subgroups of patients [97].

Interleukins are produced by the immune system and regulate many aspects of inflammation and the immune response. The present meta-analyses showed increased levels of IL-6 and IL-8 in schizophrenia spectrum disorders, whereas in affective disorders all cytokines levels were nonsignificantly increased. Other recent meta-analyses revealed evidence of increased CSF levels of IL-1 $\beta$ in schizophrenia and bipolar disorders and increased levels of IL- 6 and IL-8 in schizophrenia and depression [29, 98]. IL-6 stimulates CRP production by hepatocytes, and IL-8 primarily induces chemotaxis and phagocytosis. Increased levels of several peripheral cytokines have also been reported for schizophrenia, bipolar disorder and depression [99-101]. Although CSF cytokine levels reflect CNS inflammation more precisely, peripheral IL- 6 can reach the CNS through the choroid plexus or because of increased BBB permeability [102].

The studies on CSF antibodies could not be included in meta-analyses. Nonetheless, studies found antibodies against CNS tissue in up to $100 \%$ [20, 22, 74] and HSV-1 antibodies in up to $69 \%$ of cases with schizophrenia spectrum disorders $[48,57-59,64,70]$, but the results for most of the other infectious agents were rather conflicting. Antibodies against HSV [16, 48], Toxoplasma gondii [16] and EBV [16, 48] had the strongest associations with affective disorders. Furthermore, studies without healthy controls have found signs of CNS pathology in up to $41 \%$ of cases [93].

Antipsychotic medication has been found to increase BBB permeability in animal studies [103] and affect immune cells in the CNS [23, 104-106], highlighting the importance of evaluating the effect of psychotropic medication when analyzing CSF; however, the evidence for antidepressants is conflicting [107, 108]. Cross-sectional studies mostly found no association between CSF parameters and psychotropic medication apart from a correlation between a higher albumin ratio [88], higher IL-1alpha [78], and IL-8 [86] with antipsychotic treatment, and none of the studies investigating this aspect longitudinally.

Concerning associations with clinical symptomatology, the only CSF parameters that correlated with symptom scores were IL-8 (depression) [77], respectively albumin and IgG (schizophrenia) [6]. Increased inflammatory blood markers (e.g., CRP and IL-6) correlated with greater overall symptom severity in patients with depression, in particular with neuro-vegetative symptoms (e.g., sleep, appetite) [109-111]. However, only few studies explored associations between CSF markers and symptom severity or correlations between immune markers in serum vs. CSF, and we found conflicting results regarding correlation between IL-6 levels in CSF and serum [84, 102].

\section{Conclusion and perspectives}

The present systematic review and meta-analysis suggests that subgroups of patients with schizophrenia spectrum or affective disorders may have CSF pathology with signs of BBB impairment, intrathecal antibody synthesis and elevated levels of inflammatory markers, autoantibodies and immunoglobulins. However, CSF findings varied greatly and important confounders were often not accounted for limiting any firm conclusions regarding CSF pathology in patients with depression or schizophrenia. Therefore, future studies should be longitudinal with systematic and standardized collection of CSF samples over time in larger study populations with healthy control subjects. Preferably, these studies should include newly diagnosed patients who are naive to psychotropic drugs, with CSF measurements prior to and at several time points after psychotropic drug initiation, with adjustments for variables that can affect the immune-related markers, e.g., smoking and BMI. CSF and peripheral immune markers, in combination with peripheral blood tests and brain scans, might aid in future trials on immune-modulating add-on treatment for subgroups of mental disorders. Finally, the emerging role of the immune 
system and CNS inflammation in mental disorders necessitates improved imaging methods, better methods for sampling small amounts of CSF using small needles and guided insertions and identification of brain derived proteins in blood. Adverse events after lumbar puncture was rare and 3.2-6\% of patients received a revised (somatic) diagnosis following CSF analysis, suggesting that lumbar puncture can be an important supplemental diagnostic examination in psychiatric patient's potentially influencing treatment.

Acknowledgements The present study was partly funded by the Independent Research Fund Denmark (grant number 7025-00078B) and by an unrestricted grant from The Lundbeck Foundation (grant number R268-2016-3925). The sponsor had no role in the acquisition of the data, interpretation of the results or the decision to publish the findings.

\section{Compliance with ethical standards}

Conflict of interest The authors declare that they have no conflict of interest.

Open Access This article is licensed under a Creative Commons Attribution 4.0 International License, which permits use, sharing, adaptation, distribution and reproduction in any medium or format, as long as you give appropriate credit to the original author(s) and the source, provide a link to the Creative Commons license, and indicate if changes were made. The images or other third party material in this article are included in the article's Creative Commons license, unless indicated otherwise in a credit line to the material. If material is not included in the article's Creative Commons license and your intended use is not permitted by statutory regulation or exceeds the permitted use, you will need to obtain permission directly from the copyright holder. To view a copy of this license, visit http://creativecommons. org/licenses/by/4.0/.

\section{References}

1. Benros ME, Mortensen PB, Eaton WW. Autoimmune diseases and infections as risk factors for schizophrenia. Ann N Y Acad Sci. 2012;1262:56-6. http://www.ncbi.nlm.nih.gov/pubmed/ 22823436

2. Benros ME, Waltoft BL, Nordentoft M, Østergaard SD, Eaton WW, Krogh J, et al. Autoimmune diseases and severe infections as risk factors for mood disorders. JAMA Psychiatry. 2013;70:812. http://archpsyc.jamanetwork.com/article.aspx? doi=10.1001/jamapsychiatry.2013.1111

3. Wium-Andersen MK, Ørsted DD, Nordestgaard BG. Elevated Creactive protein and late-onset bipolar disorder in 78809 individuals from the general population. $\mathrm{Br} \mathrm{J}$ Psychiatry. 2016;208:138-45.

4. Eaton WW, Pedersen MG, Nielsen PR, Mortensen PB. Autoimmune diseases, bipolar disorder, and non-affective psychosis. Bipolar Disord. 2010;12:638-46. http://doi.wiley.com/10.1111/j. 1399-5618.2010.00853.x

5. Nikkila H, Müller K, Ahokas A, Miettinen K, Andersson LC, Rimón R. Abnormal distributions of T-lymphocyte subsets in the cerebrospinal fluid of patients with acute schizophrenia. Schizophr Res. 1995;14:215-21.
6. Müller N, Ackenheil M. Immunoglobulin and albumin content of cerebrospinal fluid in schizophrenic patients: Relationship to negative symptomatology. Schizophr Res. 1995;14:223-8.

7. Mittleman BB, Castellanos FX, Jacobsen LK, Rapoport JL, Swedo SE, Shearer GM. Cerebrospinal fluid cytokines in pediatric neuropsychiatric disease. J Immunol. 1997;159:2994-9. http://www.jimmunol.org/content/159/6/2994

8. Lindqvist D, Janelidze S, Hagell P, Erhardt S, Samuelsson M, Minthon L, et al. Interleukin-6 is elevated in the cerebrospinal fluid of suicide attempters and related to symptom severity. Biol Psychiatry. 2009;66:287-92. https://doi.org/10.1016/j.biopsych. 2009.01.030

9. Howren MB, Lamkin DM, Suls J. Associations of depression with C-reactive protein, IL-1, and IL-6: a meta-analysis. Psychosom Med [Internet]. 2009;71:171-86. http://content.wkhea lth.com/linkback/openurl?sid=WKPTLP:landingpage $\& a n=$ 00006842-200902000-00006

10. Haapakoski R, Mathieu J, Ebmeier KP, Alenius H, Kivimäki M. Cumulative meta-analysis of interleukins 6 and $1 \beta$, tumour necrosis factor $\alpha$ and C-reactive protein in patients with major depressive disorder. Brain Behav Immun. 2015;49:206-15.

11. Khandaker GM, Pearson RM, Zammit S, Lewis G, Jones PB. Association of serum interleukin 6 and $\mathrm{C}$-reactive protein in childhood with depression and psychosis in young adult life: a population-based longitudinal study. JAMA Psychiatry. 2014;71:1121-8. http://archpsyc.jamanetwork.com/article.aspx? doi $=10.1001 /$ jamapsychiatry.2014.1332

12. Ripke S, Neale BM, Corvin A, Walters JTR, Farh K-H, Holmans $\mathrm{Pa}$, et al. Biological insights from 108 schizophrenia-associated genetic loci. Nature. 2014;511:421-7. http://www.nature.com/ doifinder/10.1038/nature13595

13. Köhler O, Benros ME, Nordentoft M, Farkouh ME, Iyengar RL, Mors O, et al. Effect of anti-inflammatory treatment on depression, depressive symptoms, and adverse effects: a systematic review and meta-analysis of randomized clinical trials. JAMA Psychiatry. 2014;71:1381-91. http://archpsyc.jamanetwork. com/article.aspx?doi=10.1001/jamapsychiatry.2014.1611

14. Akhondzadeh S, Tabatabaee M, Amini H, Ahmadi Abhari SA, Abbasi SH, Behnam B. Celecoxib as adjunctive therapy in schizophrenia: a double-blind, randomized and placebocontrolled trial. Schizophr Res. 2007;90:179-85.

15. Schuld A, Uhr M, Pollmächer T. Oligoclonal bands and specific antibody indices in human narcolepsy. Somnologie. 2004;8:71-4.

16. Stich O, Andres TA, Gross CM, Gerber SI, Rauer S, Langosch JM. An observational study of inflammation in the central nervous system in patients with bipolar disorder. Bipolar Disord. 2015;17:291-302.

17. Zachrisson OCG, Balldin J, Ekman R, Naesh O, Rosengren L, Ågren $\mathrm{H}$, et al. No evident neuronal damage after electroconvulsive therapy. Psychiatry Res. 2000;96:157-65.

18. Bechter K, Herzog S, Behr W, Schüttler R. Investigations of cerebrospinal fluid in Borna disease virus seropositive psychiatric patients. Eur Psychiatry. 1995;10:250-8.

19. Bauer K, Kornhuber J. Blood-cerebrospinal fluid barrier in schizophrenic patients. Eur Arch Psychiatry Neurol Sci. 1987;236:257-9.

20. Endres D, Perlov E, Baumgartner A, Hottenrott T, Dersch R, Stich $\mathrm{O}$, et al. Immunological findings in psychotic syndromes: a tertiary care hospital's CSF sample of 180 patients. Front Hum Neurosci. 2015;9:476. http://www.pubmedcentral.nih.gov/articlerender.fcgi? artid $=4564575 \&$ tool $=$ pmcentrez\&rendertype $=$ abstract

21. Kirch DG, Kaufmann CA, Papadopoulos NM, Martin B, Weinberger DR. Abnormal cerebrospinal fluid protein indices in schizophrenia. Biol Psychiatry. 1985;20:1039-46. 
22. Bergquist J, Bergquist S, Axelsson R, Ekman R. Demonstration of immunoglobulin $\mathrm{G}$ with affinity for dopamine in cerebrospinal fluid from psychotic patients. Clin Chim Acta. 1993;217:129-42.

23. Nikkilä HV, Müller K, Ahokas A, Rimón R, Andersson LC. Increased frequency of activated lymphocytes in the cerebrospinal fluid of patients with acute schizophrenia. Schizophr Res. 2001;49:99-105.

24. Müller N, Dobmeier P, Empl M, Riedel M, Schwarz M, Ackenheil M. Soluble IL-6 receptors in the serum and cerebrospinal fluid of paranoid schizophrenic patients. Eur Psychiatry. 1997;12:294-9.

25. Kirch DG, Alexander RC, Suddath RL, Papadopoulos NM, Kaufmann CA, Daniel DG, et al. Blood-CSF barrier permeability and central nervous system immunoglobulin $\mathrm{G}$ in schizophrenia. J Neural Transm. 1992;89:219-32.

26. Bruetsch W, Bahr M, Skobba J, Dieter W. The group of dementia praecox patients with an increase of the protein content of the cerebrospinal fluid. J Nerv Ment Dis. 1942;95:669-79.

27. Pazzaglia PJ, Post RM, Rubinow D, Kling Ma, Huggins TS, Sunderland T. Cerebrospinal fluid total protein in patients with affective disorders. Psychiatry Res. 1995;57:259-66. http://www. sciencedirect.com/science/article/pii/016517819502704Z\%5Cn

28. Arias I, Sorlozano A, Villegas E, Luna J, de D, et al. Infectious agents associated with schizophrenia: A meta-analysis. Schizophr Res. 2012;136:128-36. http://www-clinicalkey-com.ep. fjernadgang.kb.dk/service/content/pdf/watermarked/1-s2.0S0920996411005615.pdf?locale $=$ en_US

29. Wang AK, Miller BJ Meta-analysis of cerebrospinal fluid cytokine and tryptophan catabolite alterations in psychiatric patients: comparisons between schizophrenia, bipolar disorder, and depression. Schizophr Bull. 2017; http://watermark.silverchair. com/api/watermark?token $=$ AQECAHi208BE49Ooan9kkhW_ Ercy7Dm3ZL_9Cf3qfKAc485ysgAAAigwggIkBgkqhkiG9w 0BBgggIVMIICEQIBADCCAgoGCSqGSIb3DQEHATAeBglg hkgBZQMEAS4wEQQMEH01BKZZ8m-rh_ TXAgEQgIIB22UkgfAIyiJWMQdFvpNMM9erz3gA6UB931P9 uMxq_uFtJ

30. Rimon R, Nishmi M, Halonen P. Serum and CSF antibody levels to herpes simplex type 1, measles and rubella viruses in patients with schizophrenia. Ann Clin Res. 1978;10:291-3.

31. Rimon RH, Halonen P, Lebon P, Heikkilä L, Frey H, Karhula P, et al. Antibrain antibodies and Interferon in the Serum and the Cerebrospinal Fluid of Patients with Schizophrenia1. Adv Biol Psychiatry. 1983;12:161-7. http://www.karger.com/?doi=10. $1159 / 000408324$

32. King DJ, Cooper SJ, Earle JAP, Martin SJ, McFerran NV, Wisdom GB. Serum and CSF antibody titres to seven common viruses in schizophrenic patients. Br J Psychiatry. 1985;147: 145-9.

33. Barak V, Barak Y, Levine J, Nisman B, Roisman I. Changes in interleukin-1 beta and soluble interleukin-2 receptor levels in CSF and serum of schizophrenic patients. J Basic Clin Physiol Pharmacol. 1995;6:61-9.

34. Licinio J, Seibyl JP, Altemus M, Charney DS, Krystal JH. Elevated CSF levels of interleukin-2 in neuroleptic-free schizophrenic patients. Am J Psychiatry. 1993;150:1408-10.

35. Katila H, Hurme M, Wahlbeck K, Appelberg B, Rimon R. Plasma and cerebrospinal fluid interleukin-1 beta and interleukin6 in hospitalized schizophrenic patients. Neuropsychobiology. 1994;30:20-3. http://ovidsp.ovid.com/ovidweb.cgi?T=JS\& $\mathrm{PAGE}=$ reference $\& \mathrm{D}=$ med $3 \& \mathrm{NEWS}=\mathrm{N} \& \mathrm{AN}=7969854$

36. Leweke FM, Gerth CW, Koethe D, Klosterkötter J, Ruslanova I, Krivogorsky B, et al. Antibodies to infectious agents in individuals with recent onset schizophrenia. Eur Arch Psychiatry Clin Neurosci. 2004;254:4-8.
37. Nikkilä HV, Müller K, Ahokas A, Miettinen K, Rimón R, Andersson LC. Accumulation of macrophages in the CSF of schizophrenic patients during acute psychotic episodes. Am J Psychiatry. 1999;156:1725-9.

38. Albrecht P, Boone E, Torrey EF, Hicks JT, Daniel N. Raised cytomegalovirus-antibody level in cerebrospinal fluid of schizophrenic patients. Lancet. 1980;2:769-72.

39. Torrey E, Albrecht P, Behr D. Permeability of the blood-brain barrier in psychiatric patients. Am J Psychiatry. 1985;142:657-8.

40. Hoerster SJ, Hillman F, Bohls S, Lara F, Thurman N. Cerebrospinal fluid in mental diseases (a study using paper electrophoresis). Dis Nerv Syst. 1963;24:357-60.

41. Selecki B, Todd P, Westwood A, Kraus J. Cerebro-spinal fluid and serum protein profiles in deteriorated epileptics, mental defectives with epilepsy, and schizophrenics. Med J Aust. 1964;2:751-3.

42. Shanmugam A. A study of cerebrospinal fluid proteins in schizophrenia. J Indian Med Assoc. 1971;57:206-8.

43. Deutsch SI, Mohs RC, Levy MI, Rothpearl AB, Stockton D, Horvath T, et al. Acetylcholinesterase activity in CSF in schizophrenia, depression, Alzheimer's disease and normals. Biol Psychiatry. 1983;18:1363-73. http://www.ncbi.nlm.nih.gov/ entrez/query.fcgi? $\mathrm{cmd}=$ Retrieve $\& \mathrm{db}=$ PubMed\&dopt $=$ Citation\&list_uids $=6661467$.

44. Nikkilä HV, Ahokas A, Wahlbeck K, Rimón R, Andersson LC. Neopterin and macrophage inflammatory protein-1alpha in the cerebrospinal fluid of schizophrenic patients: no evidence of intrathecal inflammation. Neuropsychobiology. 2002;46:169-72. www.karger.com.

45. Torrey E, Yolken R, Winfrey J. Cytomegalovirus antibody in cerebrospinal fluid of schizophrenic patients detected by enzyme immunoassay. Science. 1982;216:892-4. http://www.jstor.org/ stable/1687554\%5Cn

46. Pitts AF, Carroll BT, Gehris TL, Kathol RG, Samuelson SD. Elevated CSF protein in male patients with depression. Biol Psychiatry. 1990;28:629-37.

47. Levine J, Barak Y, Chengappa K, Rapoport A, Antelman S, Barak V. Low CSF soluble interleukin 2 receptor levels in acute depression. Short Commun J Neural Transm. 1999;106: 1011-5.

48. Gotlieb-Stematsky T, Zonis J, Arlazoroff A, Mozes T, Sigal M, Szekely AG. Antibodies to Epstein-Barr virus, herpes simplex type 1, cytomegalovirus and measles virus in psychiatric patients. Arch Virol. 1981;67:333-9.

49. Kumar A, Tewari SC, Lal N, Trivedi JK, Bahuguna LM. A study of abnormal CSF total proteins and immunoglobulins levels in patients of depression. Indian J Physiol Pharmacol. 1986;30: $103-6$.

50. Leonardi A, Cocito L, Tabaton M, Bartolini A, Roccatagliata G. $\mathrm{CSF}$ and serum $\mathrm{IgG}$ and albumin in schizophrenics. IRCS. Med Sci. 1982;10:812-3.

51. Axelsson R, Martensson E, Alling C. Impairment of the bloodbrain barrier as an aetiological factor in paranoid psychosis. Br J Psychiatry. 1982;141:273-81.

52. Tiwari SG, Lal N, Trivedi JK, Sayeed J, Bahauguna LM. Immunoglobulin patterns in schizophrenic patients. Indian $\mathrm{J}$ Psychiatry. 1984;26:223-8. http://www.ncbi.nlm.nih.gov/ pubmed/21965989\%5Cn

53. Delisi LE, Weinberger DR, Potkin S, Neckers LM, Shiling DJ, Wyatt RJ. Quantitative determination of immunoglobulins in CSF and plasma of chronic schizophrenic patients. Br J Psychiatry. 1981;139:513-8.

54. Schwarz MJ, Ackenheil M, Riedel M. Norbert Müller. Bloodcerebrospinal fluid barrier impairment as indicator for an immune process in schizophrenia. Neurosci Lett. 1998;253:201-3. 
55. Tiwari SG, Lal N, Trivedi JK, Chaturvedi UC, Varma SL, Bahauguna LM. Immunoglobulins and viral antibodies in depressive patients. Indian J Psychiatry. 1990;32: 318-23.

56. Zhu H, Wang D, Liu X. The reduction of CSF tumor necrosis factor alpha levels in schizophrenia: no correlations with psychopathology and coincident metabolic characteristics. Neuropsychiatr Dis Treat. 2016;12:2869-74.

57. Libíková H, Breier S, Kocisová M, Pogády J, Stünzner D, Ujházyová D. Assay of interferon and viral antibodies in the cerebrospinal fluid in clinical neurology and psychiatry. Acta Biol Med Ger. 1979;38:879-93. http://www.ncbi.nlm.nih.gov/ pubmed/525159

58. Libíkowa H, Stancek D, Wiedermann V, Hasto J, Breier S. Psychopharmaca and electroconvulsive therapy in relation to viral antibodies and interferon. Exp Clin Study Arch Immunol Ther Exp. 1977;25:641-9.

59. Libíková H, Pogady J, Rajcani J, Skodacek I, Ciampor F, Kocisova M. Latent herpesvirus hominis 1 in the central nervous system of psychotic patients. Acta Virol. 1979;23:231-9. http:// ovidsp.ovid.com/ovidweb.cgi?T $=\mathrm{JS} \& \mathrm{PAGE}=$ reference $\& \mathrm{D}=$ med1\&NEWS $=\mathrm{N} \& \mathrm{AN}=41436$

60. Roy A, Pickar D, Ninan P, Hooks J, Paul SM. A search for interferon in the CSF of chronic schizophrenic patients. Am J Psychiatry. 1985;142:269.

61. Levine J, Barak Y, Chengappa K, Rapoport A, Rebey M, Barak V. Cerebrospinal cytokine levels in patients with acute depression. Neuropsychobiology. 1999;40:171-6. http://content.karger. com/ProdukteDB/produkte.asp?Aktion $=$ ShowAbstractBuch \&ArtikelNr $=26615 \&$ ProduktNr $=226282$

62. Stübner S, Schön T, Padberg F, Teipel SJ, Schwarz MJ, Haslinger A, et al. Interleukin-6 and the soluble IL-6 receptor are decreased in cerebrospinal fluid of geriatric patients with major depression: No alteration of soluble gp130. Neurosci Lett. 1999;259:145-8.

63. Hestad KA, Engedal K, Whist JE, Aukrust P, Farup PG, Mollnes TE, et al. Patients with depression display cytokine levels in serum and cerebrospinal fluid similar to patients with diffuse neurological symptoms without a defined diagnosis. Neuropsychiatr Dis Treat. 2016;12:817-22.

64. Srikanth S, Ravi V, Poornima KS, Shetty KT, Gangadhar BN, Janakiramaiah N. Viral antibodies in recent onset, nonorganic psychoses: correspondence with symptomatic severity. Biol Psychiatry. 1994;36:517-21.

65. Rimon R, Ahokas A, Palo J. Serum and cerebrospinal fluid antibodies to cytomegalovirus in schizophrenia. Acta Psychiatr Scand. 1986;73:642-4.

66. Sierra-Honigmann AM, Carbone KM, Yolken RH. Polymerase chain reaction (PCR) search for viral nucleic acid sequences in schizophrenia. Br J Psychiatry. 1995;166:55-60. http://www. ncbi.nlm.nih.gov/pubmed/7894877

67. Torrey EF, Peterson MR, Brannon WL, Carpenter WT, Post RM, Van Kammen DP. Immunoglobulins and viral antibodies in psychiatric patients. Br J Psychiatry. 1978;132:342-8.

68. Shrikhande S, Hirsch SR, Coleman JC, Reveley MA, Dayton R. Cytomegalovirus and schizophrenia. A test of a viral hypothesis. Br J Psychiatry. 1985;146:503-6.

69. van Kammen DP, Mann L, Scheinin M, van Kammen WB, Linnoila M. Spinal fluid monoamine metabolites and anticytomegalovirus antibodies and brain scan evaluation in schizophrenia. Psychopharmacol Bull. 1984;20:519-22. http://www. ncbi.nlm.nih.gov/entrez/query.fcgi?cmd $=$ Retrieve $\& \mathrm{db}=$ PubMed\&dopt $=$ Citation\&list_uids $=6089252$

70. Bartova L, Rajcani J, Pogady J. Herpes simplex virus antibodies in the cerebrospinal fluid of schizophrenic patients. Acta Virol. 1987;31:443-6.
71. Karlsson H, Bachmann S, Schroder J, McArthur J, Torrey EF, Yolken RH. Retroviral RNA identified in the cerebrospinal fluids and brains of individuals with schizophrenia. Proc Natl Acad Sci. 2001;98:4634-9. http://www.pnas.org.ep.fjernadgang.kb.dk/ content/98/8/4634.full.pdf

72. Deuschle M, Bode L, Heuser I, Schmider J, Ludwig H. Borna disease virus proteins in cerebrospinal fluid of patients with recurrent depression and multiple sclerosis. Lancet. 1998;352:1828-9. http://www.ncbi.nlm.nih.gov/pubmed/12589391

73. Samuelson SD, Winokur G, Pitts AF. Elevated cerebrospinal fluid protein in men with unipolar or bipolar depression. Biol Psychiatry. 1994;35:539-44. http://www.ncbi.nlm.nih.gov/ pubmed/8038297

74. Pandey RS, Gupta AK, Chaturvedi UC. Autoimmune model of schizophrenia with special reference to antibrain antibodies. Biol Psychiatry. 1981;16:1123-36. http://www.ncbi.nlm.nih.gov/ pubmed/6186298

75. Endres D, Dersch R, Hottenrott T, Perlov E, Maier S, van Calker $\mathrm{D}$, et al. Alterations in cerebrospinal fluid in patients with bipolar syndromes. Front Psychiatry. 2016;7:1-8. http://journal. frontiersin.org/article/10.3389/fpsyt.2016.00194/full

76. Endres D, Perlov E, Dersch R, Baumgartner A, Hottenrott T, Berger B, et al. Evidence of cerebrospinal fluid abnormalities in patients with depressive syndromes. J Affect Disord. 2016;198:178-84. http://linkinghub.elsevier.com/retrieve/pii/ S0165032716301136

77. Kern S, Skoog I, Börjesson-Hanson A, Blennow K, Zetterberg $\mathrm{H}$, Östling $\mathrm{S}$, et al. Higher CSF interleukin-6 and CSF interleukin-8 in current depression in older women. Results from a population-based sample. Brain Behav Immun. 2014;41:55-8. https://doi.org/10.1016/j.bbi.2014.05.006

78. McAllister CG, Van Kammen DP, Rehn TJ, Miller AL, Gurklis $\mathrm{J}$, Kelley ME, et al. Increases in CSF levels of interleukin-2 in schizophrenia: effects of recurrence of psychosis and medication status. Am J Psychiatry. 1995;152:1291-7.

79. El-Mallakh RS, Suddath RL, Wyatt RJ. Interleukin-1 alpha and interleukin-2 in cerebrospinal fluid of schizophrenic subjects. Prog Neuropsychopharmacol Biol Psychiatry. 1993;17:383-91.

80. Garver DL, Tamas RL, Holcomb JA. Elevated interleukin-6 in the cerebrospinal fluid of a previously delineated Schizophrenia subtype. Neuropsychopharmacology. 2003;28:1515-20. http:// www.nature.com/doifinder/10.1038/sj.npp.1300217.

81. Janelidze S, Ventorp F, Erhardt S, Hansson O, Minthon L, Flax J, et al. Altered chemokine levels in the cerebrospinal fluid and plasma of suicide attempters. Psychoneuroendocrinology. 2013;38:853-62. https://doi.org/10.1016/j.psyneuen.2012.09.010

82. Van Kammen DP, McAllister-Sistilli CG, Kelley ME, Gurklis JA, Yao JK. Elevated interleukin-6 in schizophrenia. Psychiatry Res. 1999;87:129-36.

83. Yao JK, Sistilli CG, Van Kammen DP. Membrane polyunsaturated fatty acids and CSF cytokines in patients with schizophrenia. Prostaglandins Leukot Essent Fat Acids. 2003;69:429-36.

84. Sasayama D, Hattori K, Wakabayashi C, Teraishi T, Hori H, Ota $\mathrm{M}$, et al. Increased cerebrospinal fluid interleukin-6 levels in patients with schizophrenia and those with major depressive disorder. J Psychiatr Res. 2013;47:401-6.

85. Schwieler L, Larsson MK, Skogh E, Kegel ME, Orhan F, Abdelmoaty S, et al. Increased levels of IL-6 in the cerebrospinal fluid of patients with chronic schizophrenia-significance for activation of the kynurenine pathway. J Psychiatry Neurosci. 2015;40:126-33. http://jpn.ca/vol40-issue2/40-2-126/

86. Isgren A, Jakobsson J, Pålsson E, Ekman CJ, Johansson AGM, Sellgren $\mathrm{C}$, et al. Increased cerebrospinal fluid interleukin-8 in bipolar disorder patients associated with lithium and 
antipsychotic treatment. Brain Behav Immun. 2015;43:198-204. https://doi.org/10.1016/j.bbi.2014.10.001

87. Janelidze S, Suchankova P, Ekman A, Erhardt S, Sellgren C, Samuelsson M, et al. Low IL-8 is associated with anxiety in suicidal patients: genetic variation and decreased protein levels. Acta Psychiatr Scand. 2015;131:269-78.

88. Zetterberg H, Jakobsson J, Redsäter M, Andreasson U, Pålsson $\mathrm{E}$, Ekman CJ, et al. Blood-cerebrospinal fluid barrier dysfunction in patients with bipolar disorder in relation to antipsychotic treatment. Psychiatry Res. 2014;217:143-6. https://doi.org/10. 1016/j.psychres.2014.03.045

89. Gudmundsson P, Skoog I, Waern M, Blennow K, Pálsson S, Rosengren L, et al. The relationship between cerebrospinal fluid biomarkers and depression in elderly women. Am J Geriatr Psychiatry. 2007;15:832-8.

90. Söderlund J, Schröder J, Nordin C, Samuelsson M, WaltherJallow L, Karlsson H, et al. Activation of brain interleukin- $1 \beta$ in schizophrenia. Mol Psychiatry. 2009;14:1069-71. https://doi. org/10.1038/mp.2009.52

91. Brettschneider J, Claus A, Kassubek J, Tumani H. Isolated blood-cerebrospinal fluid barrier dysfunction: Prevalence and associated diseases. J Neurol. 2005;252:1067-73.

92. Kranaster L, Koethe D, Hoyer C, Meyer-Lindenberg A, Leweke FM. Cerebrospinal fluid diagnostics in first-episode schizophrenia. Eur Arch Psychiatry Clin Neurosci. 2011;261:529-30. https://doi.org/10.1007/s00406-011-0193-7

93. Bechter K, Reiber H, Herzog S, Fuchs D, Tumani H, Maxeiner HG. Cerebrospinal fluid analysis in affective and schizophrenic spectrum disorders: Identification of subgroups with immune responses and blood-CSF barrier dysfunction. J Psychiatr Res. 2010;44:321-30. http://linkinghub.elsevier.com/retrieve/pii/ S0022395609001848

94. Reiber H, Peter JB. Cerebrospinal fluid analysis: disease related data patterns and evaluation progams. $J$ Neurol Sci. 2001;184:101-22. www.elsevier.com

95. Wildemann B, Oschmann P, Reiber H. Laboratory diagnosis in neurological disorders. 2010.

96. Powell TR, Gaspar H, Chung R, Keohane A, Gunasinghe C, Uher R, et al. Assessing 42 inflammatory markers in 321 control subjects and 887 major depressive disorder cases: BMI and other confounders and overall predictive ability for current depression. Biorxiv. 2018. https://doi.org/10.1101/327239

97. Wright BLC, Lai JTF, Sinclair AJ. Cerebrospinal fluid and lumbar puncture: a practical review. J Neurol. 2012;259: $1530-45$.

98. Miller BJ, Buckley P, Seabolt W, Mellor A, Kirkpatrick B. Meta-analysis of cytokine alterations in schizophrenia: Clinical status and antipsychotic effects. Biol Psychiatry. 2011;70: 663-71.

99. Goldsmith DR, Rapaport MH, Miller BJ. A meta-analysis of blood cytokine network alterations in psychiatric patients: comparisons between schizophrenia, bipolar disorder and depression. Mol Psychiatry. 2016; http://www.nature.com/doifinder/ 10.1038/mp.2016.3\%5Cnhttp://www.ncbi.nlm.nih.gov/pubmed/ 26903267

100. Potvin S, Stip E, Sepehry AA, Gendron A, Bah R, Kouassi E. Inflammatory cytokine alterations in Schizophrenia: a systematic quantitative review. Biol Psychiatry. 2008;63:801-8. http://ac. els-cdn.com.ep.fjernadgang.kb.dk/S0006322307009481/1-s2.0S0006322307009481-main.pdf?_tid=a46b1c14-9ec4-11e7-8a 0b-00000aacb362\&acdnat $=1505995487 \_8$ e9516a45237483a d0684a89e933556b

101. Dowlati Y, Herrmann N, Swardfager W, Liu H, Sham L, Reim EK, et al. A meta-analysis of cytokines in major depression. Biol Psychiatry. 2010;67:446-57. http://ac.els-cdn.com.ep.fjernadga ng.kb.dk/S0006322309012293/1-s2.0-S0006322309012293-ma in.pdf?_tid=eb18a960-9ec4-11e7-a5a7-00000aab0f6b\&acdnat= 1505995605_cab60f388110f8409eec8777f7c4680f

102. Coughlin JM, Wang Y, Ambinder EB, Ward RE, Minn I, Vranesic $\mathrm{M}$, et al. In vivo markers of inflammatory response in recent-onset schizophrenia: a combined study using [(11)C] DPA-713 PET and analysis of CSF and plasma. Transl Psychiatry. 2016;6:e777 https://doi.org/10.1038/tp.2016.40

103. Saija A, Princi P, Imperatore C, De Pasquale R, Costa G. Ageing influences haloperidol-induced changes in the permeability of the blood-brain barrier in the rat. $\mathrm{J}$ Pharm Pharmacol. 1992;44:450-2.

104. Heiser P, Enning F, Krieg J, Vedder H. Effects of haloperiodol, clozapine and olanzapine on the survival of human neuronal and immune cells in vitro. J Psychopharmacol. 2007;21:851-6.

105. Hirata-Hibi M, Higashi S, Tachibana T, Watanabe N. Stimulated lymphocytes in schizophrenia. Arch Gen Psychiatry. 1982;39:82-7.

106. Torrey EF, Upshaw YD, Suddath R. Medication effect on lymphocyte morphology in schizophrenia. Schizophr Res. 1989;2:385-90.

107. Elmorsy E, Al-Ghafari A, Almutairi FM, Aggour AM, Carter WG. Antidepressants are cytotoxic to rat primary blood brain barrier endothelial cells at high therapeutic concentrations. Toxicol Vitr. 2017;44:154-63. http://ac-els-cdn-com.ep.fjerna dgang.kb.dk/S0887233317301972/1-s2.0-S0887233317301972main.pdf?_tid=b6a8f7ff-3cff-4677-8d0b-27bc0a473af5\&acdna $\mathrm{t}=1523906889$ 5e2d2f1a2f414f263ebabf8b28b253b1

108. Lee JY, Kim HS, Choi HY, Oh TH, Yune TY. Fluoxetine inhibits matrix metalloprotease activation and prevents disruption of blood-spinal cord barrier after spinal cord injury. Brain. 2012;135:2375-89.

109. Krogh J, Benros ME, Jørgensen MB, Vesterager L, Elfving B, Nordentoft $\mathrm{M}$. The association between depressive symptoms, cognitive function, and inflammation in major depression. Brain Behav Immun. 2014;35:70-6. https://doi.org/10.1016/j.bbi.2013. 08.014

110. Yoon H-K, Kim Y-K, Lee H-J, Kwon D-Y, Kim L. Role of cytokines in atypical depression. Nord J Psychiatry. 2012;66:183-8. https://doi.org/10.3109/08039488.2011.611894

111. Köhler-Forsberg O, Buttenschøn HN, Tansey KE, Maier W, Hauser J, Dernovsek MZ, et al. Association between C-reactive protein (CRP) with depression symptom severity and specific depressive symptoms in major depression. Brain Behav Immun. 2017;62:344-50. http://ac.els-cdn.com.ep.fjernadgang.kb.dk/ S0889159117300624/1-s2.0-S0889159117300624-main.pdf? tid $=5870$ ce64-9611-11e7-b44a-00000aab0f01\&acdnat $=$ 1505038870_96534e22a803f45c0f79d9afbfc1f299

112. Roos R, Davis K, Meltzer H. Immunoglobulin studies in patients with psychiatric diseases. Arch Gen Psychiatry. 1985;42:124-8.

113. Harrington MG, Merril CA, Tone EF. Differences in cerebrospinal fluid proteins between patients with schizophrenia and normal persons. Clin Chem. 1985;31:722-6.

114. Rapaport MH, McAllister CG, Pickar D, Tamarkin L, Kirch DG, Paul SM. CSF IL-1 and IL-2 in medicated schizophrenic patients and normal volunteers. Schizophr Res. 1997;25:123-9.

115. Vawter MP, Dillon-Carter O, Issa F, Wyatt RJ, Freed WJ. Transforming growth factors beta 1 and beta 2 in the cerebrospinal fluid of chronic schizophrenic patients. Neuropsychopharmacology. 1997;16:83-7. http://ac.els-cdn.com.ep.fjernadgang.kb.dk/ S0893133X96001431/1-s2.0-S0893133X96001431-main.pdf? _tid=7a62b708-988c-11e7-9080-00000aacb35f\&acdnat= 1505311657 9ed50217b7d6719fed5b737be02343e4

116. Bendikov I, Nadri C, Amar S, Panizzutti R, De Miranda J, Wolosker $\mathrm{H}$, et al. A CSF and postmortem brain study of dserine metabolic parameters in schizophrenia. Schizophr Res. 2007;90:41-51. 
117. Hayes LN, Severance EG, Leek JT, Gressitt KL, Rohleder C, Coughlin JM, et al. Inflammatory molecular signature associated with infectious agents in psychosis. Schizophr Bull. 2014;40:963-72.

118. Severance EG, Gressitt KL, Alaedini A, Rohleder C, Enning F, Bumb JM, et al. IgG dynamics of dietary antigens point to cerebrospinal fluid barrier or flow dysfunction in first-episode schizophrenia. Brain Behav Immun. 2015;44:148-58. https://doi. org/10.1016/j.bbi.2014.09.009

119. Hampel H, Kötter HU, Möller H-J. Blood-cerebrospinal fluid barrier dysfunction for high molecular weight proteins in Alzheimer disease and major depression. Alzheimer Dis Assoc Disord. 1997;11:78-87. http://content.wkhealth.com/linkback/ openurl?sid=WKPTLP:landingpage $\&$ an $=00002093-$ 199706000-00004

120. Hampel H, Kotter HU, Padberg F, Korschenhausen DA, Moller HJ Oligoclonal bands and blood--cerebrospinal-fluid barrier dysfunction in a subset of patients with Alzheimer disease: comparison with vascular dementia, major depression, and multiple sclerosis. [Internet]. Alzheimer disease and associated disorders. 1999;9-19. http://ovidsp.ovid.com/ovidweb.cgi?T= $\mathrm{JS} \& \mathrm{PAGE}=$ reference $\& \mathrm{D}=$ med 4 \&EWS $=\mathrm{N} \& A N=10192637$

121. Carpenter LL, Heninger GR, Malison RT, Tyrka AR, Price LH. Cerebrospinal fluid interleukin (IL)-6 in unipolar major depression. J Affect Disord. 2004;79:285-9.
122. Pålhagen S, Qi H, Mårtensson B, Wålinder J, Granérus AK, Svenningsson P. Monoamines, BDNF, IL-6 and corticosterone in CSF in patients with Parkinson's disease and major depression. J Neurol. 2010;257:524-32. https://link-springer-com.ep.fjernadga ng.kb.dk/content/pdf/10.1007\%2Fs00415-009-5353-6.pdf

123. Söderlund J, Olsson SK, Samuelsson M, Walther-Jallow L, Johansson C, Erhardt S, et al. Elevation of cerebrospinal fluid interleukin-1 $\beta$ in bipolar disorder. J Psychiatry Neurosci. 2011;36:114-8.

124. Martinez JM, Garakani A, Yehuda R, Gorman JM. Proinflammatory and "resiliency" proteins in the CSF of patients with major depression. Depress Anxiety. 2012;29:32-8.

125. Ueno Y, Kuraishi F, Uematsu S, Tsuruoka T. Qualitative differences between protein in blood serum and in cerebrospinal fluid of psychotics-the polarographic and electrophoretic studies. Folia Psychiatr Neurol Jpn. 1968;22: 167-84

126. Preble OT, Torrey EF. Serum interferon in patients with psychosis. Am J Psychiatry. 1985;142:1184-6.

127. Coughlin JM, Ishizuka K, Kano SI, Edwards JA, Seifuddin FT, Shimano MA, et al. Marked reduction of soluble superoxide dismutase-1 (SOD1) in cerebrospinal fluid of patients with recent-onset schizophrenia. Mol Psychiatry. 2013;18:10-1. http://www.ncbi.nlm.nih.gov/pubmed/22349781

\section{Affiliations}

\section{Sonja Orlovska-Waast ${ }^{1,2} \cdot$ Ole Köhler-Forsberg $\mathbb{1}^{1,3,4} \cdot$ Sophie Wiben Brix ${ }^{1} \cdot$ Merete Nordentoft $^{1,2}$. Daniel Kondziella ${ }^{5,6} \cdot$ Jesper Krogh ${ }^{1} \cdot$ Michael Eriksen Benros $^{1}$}

1 Mental Health Centre Copenhagen, University of Copenhagen, Faculty of Health Sciences, Copenhagen, Denmark

2 iPSYCH The Lundbeck Foundation Initiative for Integrative Psychiatric Research, Aarhus, Denmark

3 Psychosis Research Unit, Aarhus University Hospital, Risskov, Denmark
4 Department of Clinical Medicine, Aarhus University, Aarhus, Denmark

5 Department of Neurology, Rigshospitalet, Copenhagen University Hospital, Copenhagen, Denmark

6 Department of Neuroscience, Norwegian University of Science and Technology, Trondheim, Norway 